\title{
Possible Neolithic ard marks and field boundaries at Wellhill and Cranberry, Perth and Kinross, and an evaluation of current physical evidence for Neolithic farming in Scotland
}

\author{
Kenneth Brophy ${ }^{*}$ and Dene Wright ${ }^{\dagger}$
}

\begin{abstract}
Although the Neolithic period is defined by farming, physical evidence for processes associated with farming are rare, with agricultural practices usually indicated by environmental and biomolecular proxies for domesticates such as pollen evidence, ceramic residues and lipids, animal bones, plant remains and stable isotope studies. This paper will, we hope, invigorate discussion on the recognition, interpretation and significance of physical traces of farming in Scotland. The starting point will be the summary of two excavations, Wellhill and Cranberry, both Perth and Kinross, in 2014 and 2016 respectively, part of the Strathearn Environs and Royal Forteviot (SERF) project. These cropmark sites revealed evidence for possible Neolithic farming in the form of possible ard marks and field ditches. There follows a synthesis of physical evidence for Neolithic farming in Scotland, drawing together evidence for ard marks, field boundaries, cultivation ridges, cultivated middens, and soils. Recommendations are made for recognising and interpreting such features on excavations, and the potential benefits of giving a higher profile to the act of farming in our narratives about Neolithic lifeways in Scotland and beyond are briefly explored.
\end{abstract}

\section{INTRODUCTION}

Despite agriculture being the defining trait of the Neolithic period, there is surprisingly little physical evidence for farming activity from that period, with most insights into agriculture provided by archaeological science in Britain and Ireland. As such, discussion about the processes of farming are typically brief and lacking in detail in syntheses of the period. This has been accompanied by a lack of research into the social and cultural significance of, for instance, ploughing and creating field boundaries, and the material culture

*Archaeology, University of Glasgow, Glasgow, G12 8QQ

${ }^{\dagger}$ Archaeology, University of Glasgow, Glasgow, G12 8QQ associated with farming. This is, in part no doubt, due to the ephemeral nature of the evidence; recognising and dating features such as ard marks, cultivation soils and field ditches is problematic.

This paper aims to prompt discussion on this lacuna in Neolithic studies by reporting on two recent and pertinent excavations near Dunning, Perth and Kinross. Investigations of two cropmark sites, Wellhill (in 2014) and Cranberry (in 2016), have revealed a series of features representing activity spanning some 9,000 years from the Mesolithic through to the early medieval periods. Discoveries include a Mesolithic

kenny.brophy@glasgow.ac.uk

dene.wright@glasgow.ac.uk 
pit-alignment, Neolithic pit clusters, later prehistoric burials and palisaded enclosures, and exceptional assemblages of Neolithic Carinated Bowl pottery. This paper will concentrate on the identification of ard marks at Wellhill and possible field boundary ditches at both sites. This was unexpected given both sites are in the plough zone.

These discoveries may be among the earliest examples of direct evidence for agricultural practice in northern Britain, although this interpretation is presented with necessary caution; indeed, this is a suitable case study for the problematic nature of making definitive assertions about such features in terms of date and function. To make this point further, and contextualise these discoveries, we will present an overview of physical farming traces of possible or probable Neolithic date in Scotland, the most complete review of this material to date. This will, we hope, catalyse similar syntheses for other parts of Britain and Ireland.

We will conclude with observations about lessons learned from identifying such ephemeral traces and make tentative suggestions as to the possible social and place-making significance of marking the surface of the land by the first farmers.

\section{EXCAVATIONS AT WELLHILL AND CRANBERRY}

Wellhill and Cranberry were both excavated as part of the Strathearn Environs and Royal Forteviot (SERF) project, a long-term landscape study of the parishes of Forteviot and Dunning from the Mesolithic to post-medieval periods (Driscoll et al 2010). The first phase of the project (2006-11) focused on a substantial Neolithic and Bronze Age monument cropmark complex at Forteviot (Noble \& Brophy 2011; Brophy $\&$ Noble 2020). The second phase (2012-17) expanded into the surrounding landscape, including a series of cropmark complexes north and west of the village of Dunning $4 \mathrm{~km}$ west of Forteviot (Illus 1). Excavations at Dunknock,
Cranberry, Baldinnies, Leadketty, Millhaugh and Wellhill took place during this programme of work, revealing, as noted above, some 8,000 years of human activity (eg Wright 2015; Wright \& Brophy in prep).

\section{WELLHILL}

At Wellhill (NO 0257 1573, Canmore ID 84910), trenches WH14.1 and WH14.2 were opened in June 2014 to facilitate examination of a pit-alignment and pits first identified as cropmarks by the former Royal Commission on the Ancient and Historical Monuments of Scotland (RCAHMS) aerial survey team in 1992 (Illus 2). These excavations took place to test our hypothesis that this was a Mesolithic site akin to an alignment of pits excavated at Warren Field, Aberdeenshire (Murray et al 2009).

In WH14.1, the pit-alignment was identified alongside several other cut features (Illus 3). Excavation and radiocarbon dating confirmed this was a Mesolithic alignment, dating to 8205$7525 \mathrm{cal}$ BC. These pits were, for the most part, left open to fill with silt for an extended period. Most were then recut in the Early Neolithic, with a series of deposits placed in these pits, including Carinated Bowl sherds, lithics and carbonised material, which could be characterised as hearth-sweepings. These recuts were probably made in the 38th century cal $\mathrm{BC}$ and appear to have deliberately focused on the Mesolithic pits, as few other Neolithic features were identified here. This cluster of Early Neolithic pits shares many characteristics of similar sites found elsewhere, including sherds from the same pot found in multiple pits, and rulebound deposition (Anderson-Whymark \& Thomas 2012), suggesting these pits were open and active repositories for deposition during the Early Neolithic. Adjacent Trench WH14.2 (Illus 4) contained only a few features, mostly pits contemporary with the Neolithic phase of activity identified in WH14.1.

During initial cleaning of both trenches, ephemeral linear features were noted. These were arranged criss-crossing one another, running 

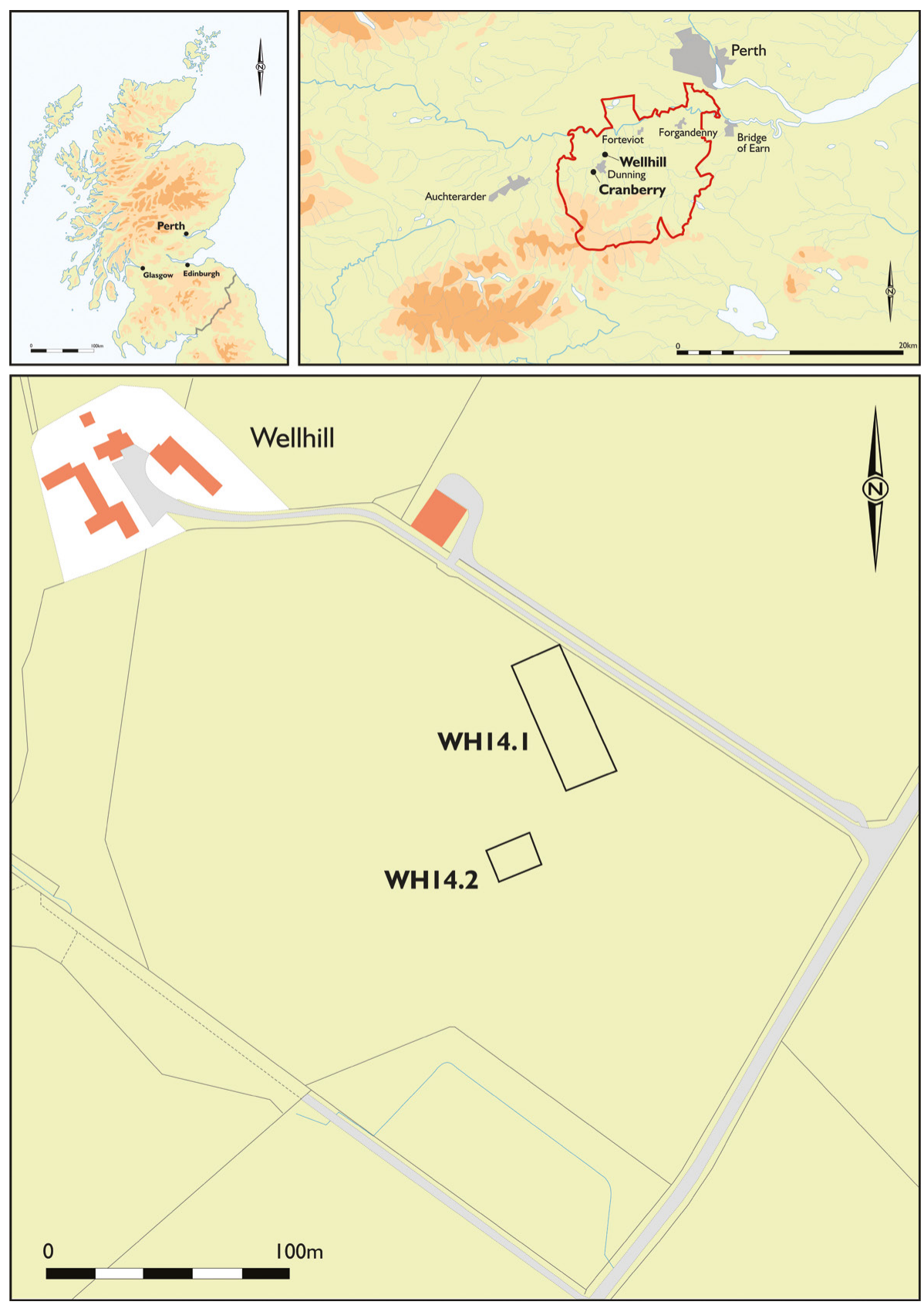

ILLus 1 Map showing the SERF Project area, Wellhill and Cranberry locations, and the relative position of Wellhill trenches WH14.1 and WH14.2. (Prepared by Lorraine McEwan)

north-east/south-west or north-west/south-east, the longest example being $7.7 \mathrm{~m}$ in length; these were interpreted as ard marks. Three (feature numbers DF0030, DF0034, DF0035) were investigated; widths ranged from $0.04 \mathrm{~m}$ to $0.11 \mathrm{~m}$ and all survived to a depth of no more than $0.04 \mathrm{~m}$. 


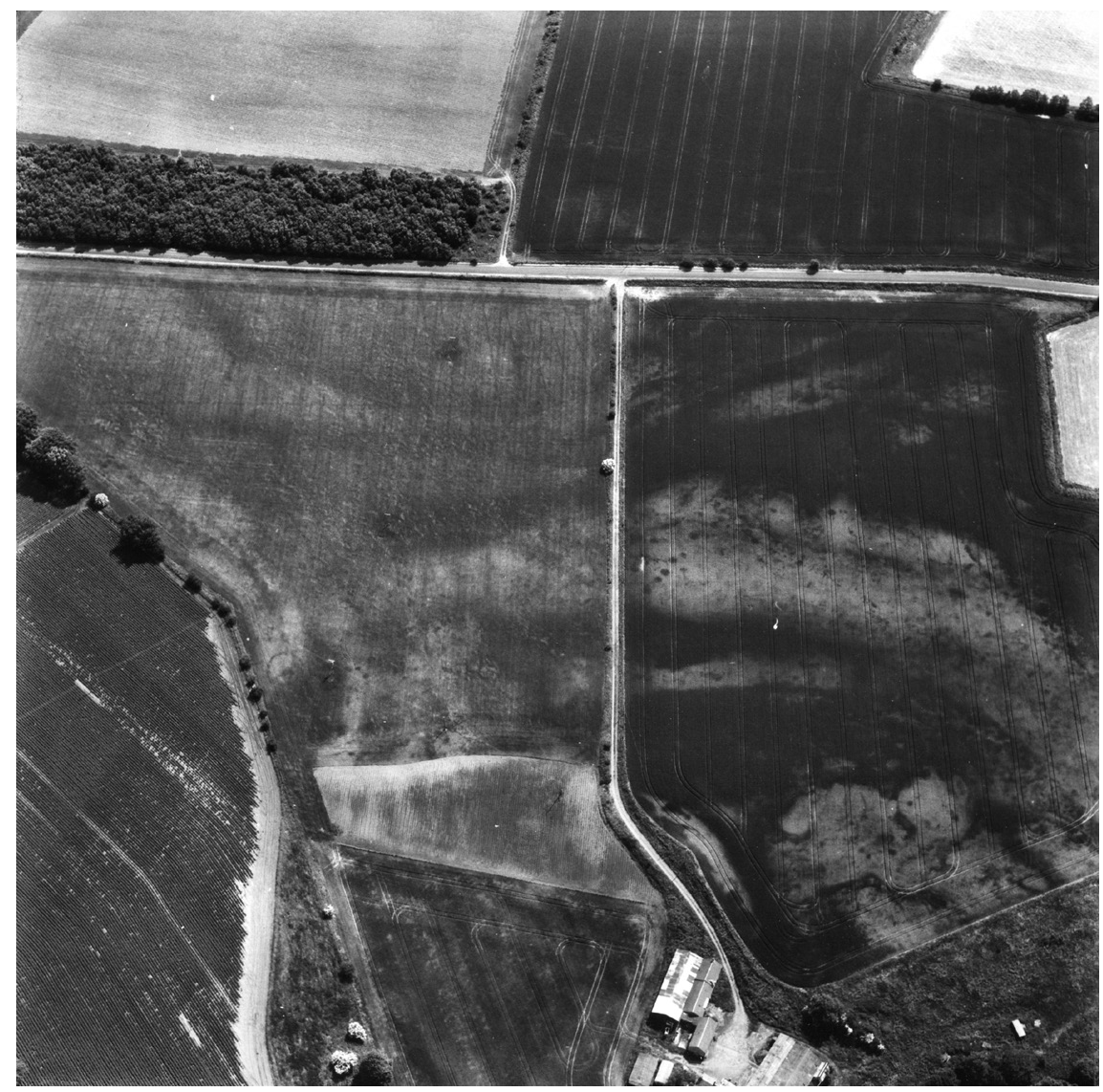

ILLus 2 Aerial photo of Wellhill, showing the Mesolithic pit-alignment as cropmarks. (C) Crown Copyright HES print number B97132)

These were clearly distinguishable from more substantial post-medieval rig and furrow cultivation noted in the vicinity to the south; these were cut deeper and broader and were more irregular in appearance. No finds or datable material were found in association with these ard marks, but one cut a right-angled slot feature (DF0021, illustrated in Illus 3) interpreted as a wind-break which itself was cut by a pit on the alignment, offering a terminus post quem for the ard mark.

The ard marks in WH14.2 were found in proximity to linear ditch-like feature DF0024 (Illus 5). This was hockey stick-shaped in plan, with both ends running beyond the baulk. The ditch was up to $0.4 \mathrm{~m}$ across, $0.2 \mathrm{~m}$ deep, with a
U-shaped profile and silt fill. It ran west/east for $6 \mathrm{~m}$, before turning sharply to the south-east at the eastern end for $3 \mathrm{~m}$. This ditch may have held a light fence, with cobbles within the feature being potential packing material. (The true extent of this feature remains unknown, and it is not visible as a cropmark on any aerial photographs taken of this locality. Therefore, it is possible the overall shape is a product of trench placement and not the original intent of the ditch diggers.) We would argue that this ditch, found in close association with ard marks, and given its apparent similarity to other examples discussed below, was a Neolithic field boundary, with associated bank removed by modern plough action. 


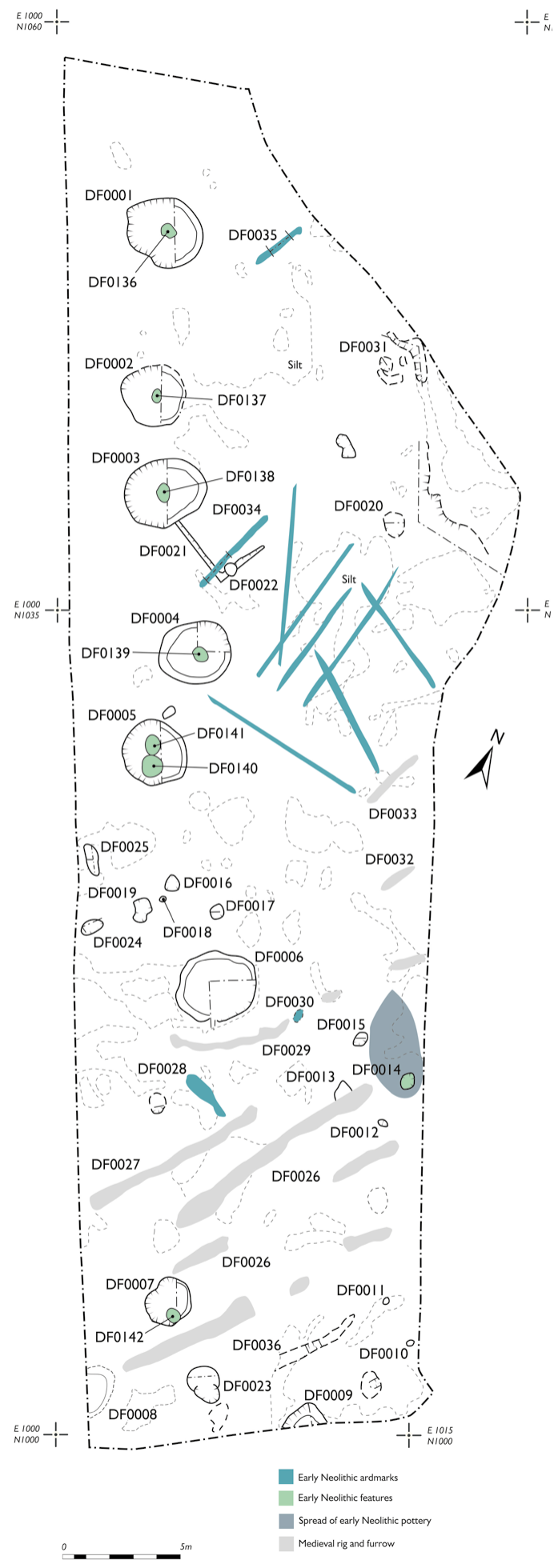

ILLus 3 Plan of Trench WH14.1. (Prepared by Lorraine McEwan)

\section{CRANBERRY}

Excavations at Cranberry (NO 0113 1415, Canmore ID 26699) focused on a single trench, opened in June 2016 (Illus 6). A complex sequence was found, over and above the features suggested by the cropmarks, showing this location was in use from the Mesolithic through to the early medieval period. Significant discoveries include Late Neolithic and Iron Age dwellings, a double cist burial, a post-alignment, post- and slot-defined palisades, fire pits, midden pits and assorted cut features. An assemblage of some 650 prehistoric potsherds was recovered, including large parts of unusually heavy Carinated Bowls (Alexander et al in prep).

Amid this profusion of cut features, nine undated linear grooves were identified that were interpreted as possible field boundary ditches (Illus 7). Four had the 'hockey stick' morphology in plan noted at Wellhill. Seven were test-excavated. The width varied from $0.5 \mathrm{~m}$ to $0.53 \mathrm{~m}$, and depth from $0.14 \mathrm{~m}$ to $0.25 \mathrm{~m}$; the longest example (DS005) was $5 \mathrm{~m}$ in length. The only evidence that these ditches held a fence other than a compacted soil and stone matrix is recorded at DS005, with a stake-hole acting as a possible anchor support at the 'hockey stick' angle.

We have no direct dating evidence for the Wellhill and Cranberry agricultural features and their ephemerality made them difficult to record in gravel subsoils. However, we would argue based on morphology, and proximity to Neolithic features and materials, that these are likely to be Neolithic. For instance, ditch DS008 at Cranberry is cut by a double cist of likely Late Neolithic or Early Bronze Age origin, offering a terminus ante quem for the ditch. At Wellhill, the ard marks respect the pit cluster, while sherds of Early Neolithic pottery were recovered from the subsoil surface in the immediate vicinity of the marks in both trenches, the only places in this site where this phenomenon occurred (indicated on Illus 3).

There is also environmental evidence that farming was taking place in the Neolithic period in proximity to Cranberry and Wellhill. Carbonised cereals, mostly of indeterminate 


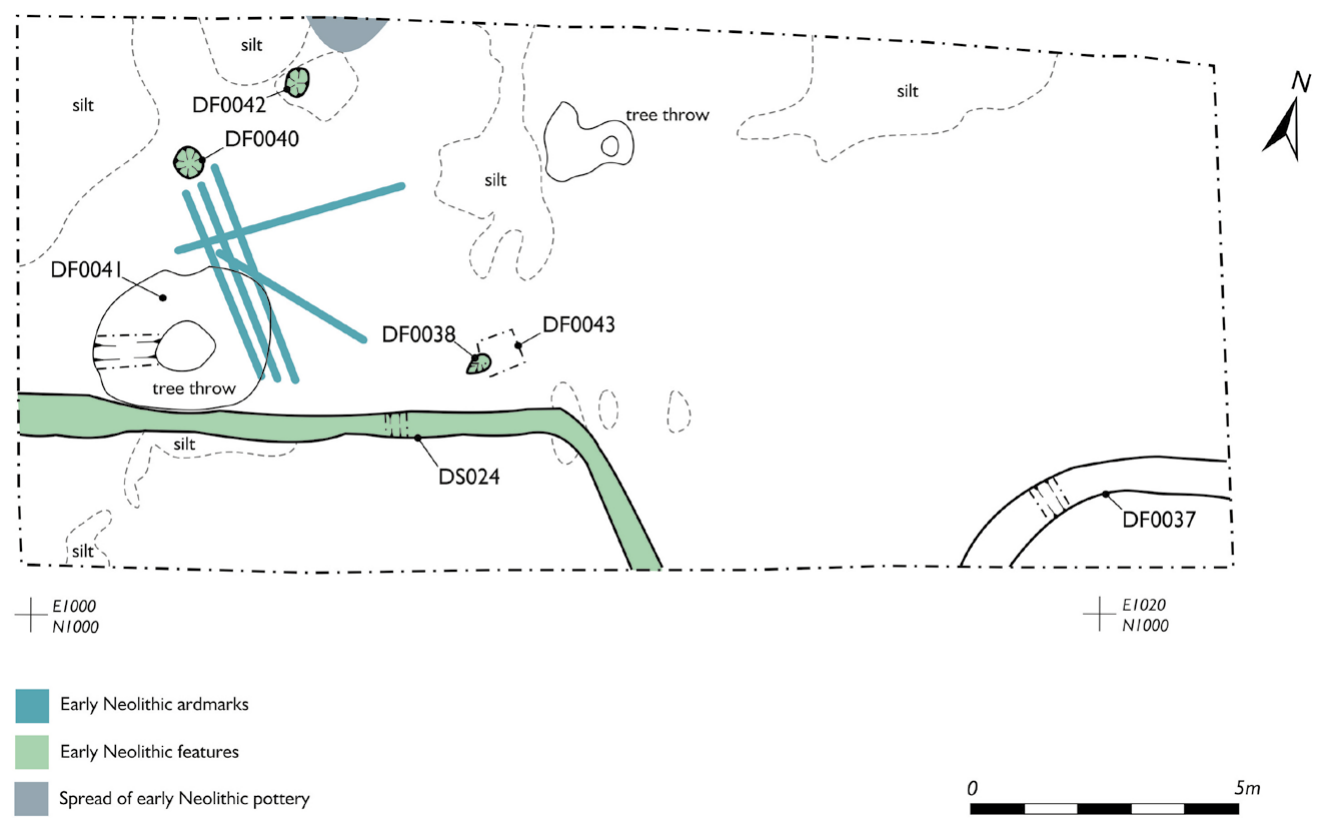

ILLus 4 Plan of Trench WH14.2. (Prepared by Lorraine McEwan)

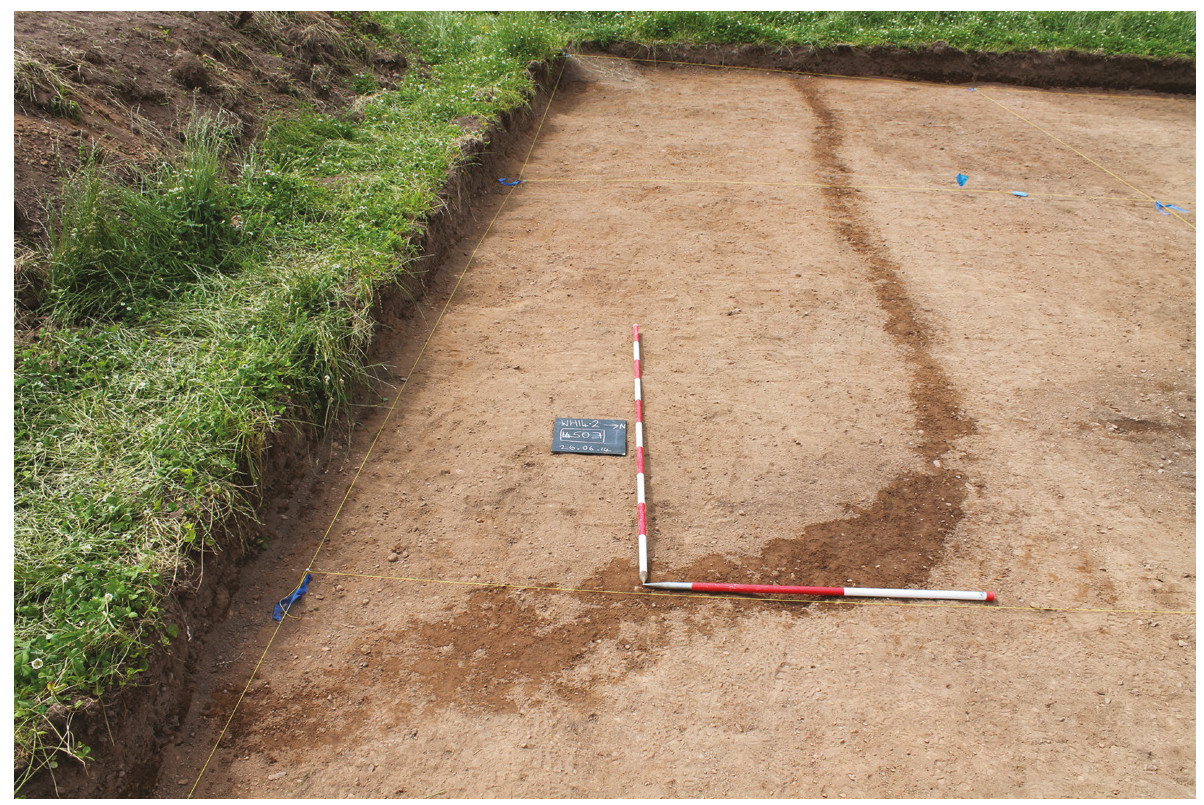

ILLus 5 Putative field boundary ditch, trench WH14.2. (Courtesy of SERF Project) 


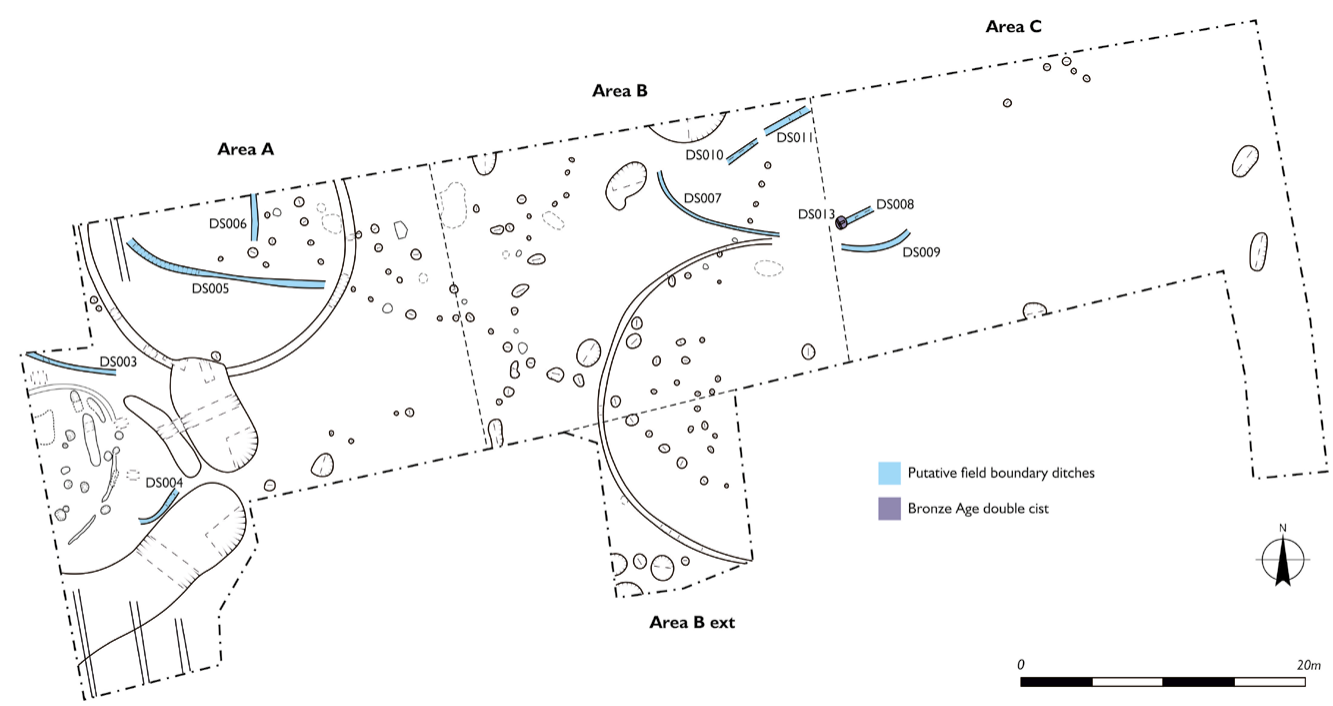

ILLus 6 Plan of the Cranberry 2016 trench with relevant features (putative field ditches and a Bronze Age cist that cuts into one of these ditches) highlighted. Other features have been greyed out. (Prepared by Lorraine McEwan)

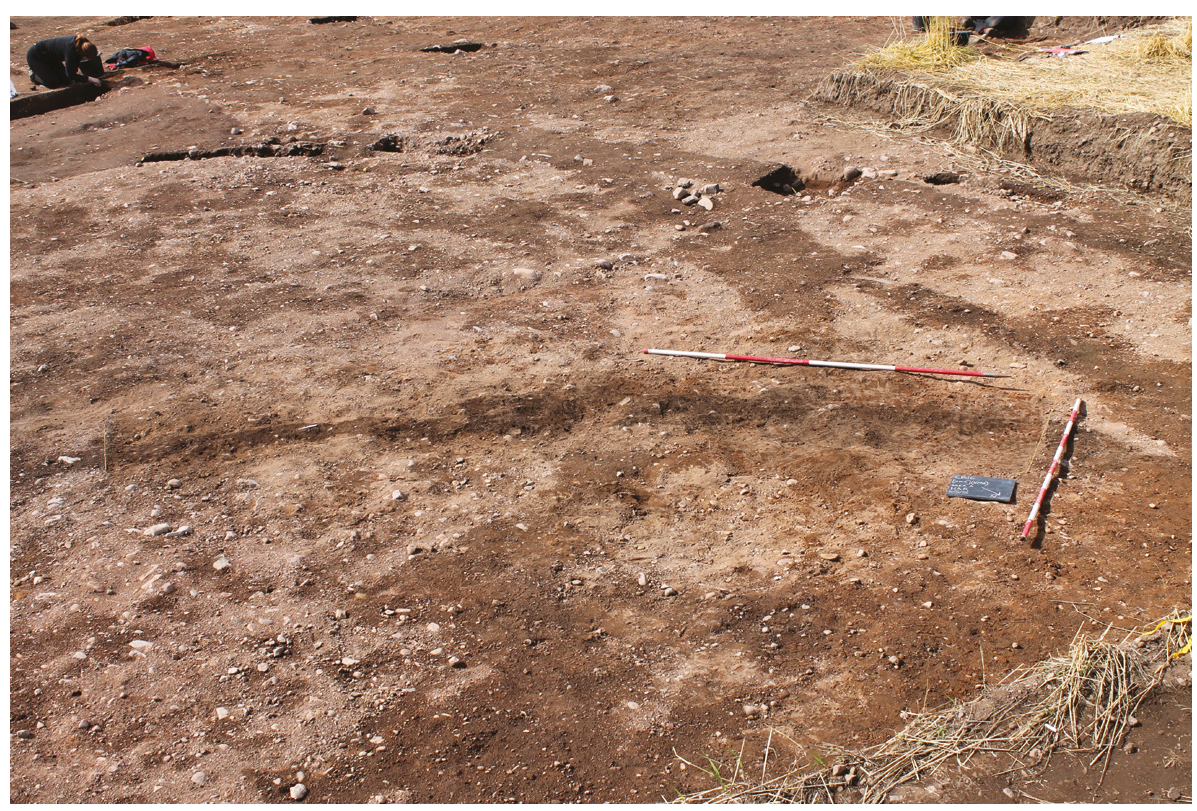

ILlus 7 Possible field ditches at Cranberry. (Courtesy of SERF Project) 
type, were found in a few pits at Wellhill, with one grain (Triticum aestivum, bread wheat) dated to $3768-3655$ cal BC $(4936 \pm 25$ BP; SUERC66241), suggesting that Early Neolithic farming occurred in this location. Carbonised wheat and barley grains were also found within features that produced Neolithic radiocarbon dates and/or material culture at Cranberry.

Other interpretations are of course possible for the linear features discussed above. However, by suggesting that they are field ditches and ard marks, we are flagging these up for future evaluation in the context of prehistoric farming, and we prefer to attempt a reasoned interpretation than discuss these in more neutral terms, accepting that in the future we may be proved wrong. A further indicator that these ard marks and ditches may have been Neolithic is their similarity to features found elsewhere in Scotland, and it is to this broader context that we now turn.

\section{EVIDENCE FOR NEOLITHIC FARMING IN SCOTLAND}

The significance of the ard marks and possible field ditches found at Wellhill and Cranberry is indicated by the relative paucity of similar evidence elsewhere in Scotland, particularly in mainland, lowland contexts. The nature of agriculture (and sedentism) throughout the Neolithic in Scotland is open to debate (cf Barclay 2003; Brophy 2006; Bishop et al 2009; ScARF 2012: section 4.1.2.4) in no small part due to the lack of direct evidence for ploughing or field boundaries. Nonetheless, it is clear that domesticates were in use from the beginning of the Neolithic period in northern Britain (Bishop et al 2009).

There are two broad categories of evidence for farming. Firstly, physical evidence such as field boundaries, lynchets, plough marks, spade marks and ard marks, cultivation ridges, field clearance cairns, and soil transformations, all of which are indicative of new practices impacting on the land and its organisation. Secondly, environmental and biomolecular proxies for agriculture at various levels of precision - pollen and other environmental evidence, cereal impressions on ceramics, animal bones, archaeobotanical evidence, material culture such as quernstones, and evidence for manuring and fertilising. This review will focus for the most part on the former body of evidence (for detailed reviews of the latter in Scotland, see for instance Guttmann 2005; Brophy 2006; Noble 2006; Bishop et al 2009; Becket \& MacGregor 2011; see also ScARF 2012: section 4.4). Broader regional perspectives are briefly discussed below.

Physical evidence for farming forms a dataset beset with problems related to bias, recognition, expectation and chronology. There is an inevitable topographic and geographic bias towards places that have been little disturbed since prehistory due to the ephemerality of features such as ard marks, hence a preponderance of evidence in inland and, to a lesser extent, upland locations. Lowland farming evidence has almost all been found beneath prehistoric barrows or other structures (cf Ashbee et al 1979; Noble 2006; Thomas 2013) and has thus been both protected and a target for investigation. Logic dictates that we are more likely to find physical evidence for cultivation where we are more likely to excavate.

There is also an issue of recognition. Barclay (2003: 131) noted that upland earthworks, possible contenders for field systems, are rarely if ever considered to be Neolithic, a point also made by Loveday (2016) in relation to the identification of upland cursus monuments. Kinnes (1985: 29) pointed out that some cropmark pit-alignments may be fence, pitted or earthwork field divisions of Neolithic date. However, all excavated cropmark land divisions in Scotland thus far have been shown to be Iron Age or later (cf Halliday et al 1981), while the ditches at Wellhill and Cranberry are not visible as cropmarks, even with the benefit of post-excavation hindsight. Some more thoughts on strategies for identifying physical traces of farming of possible Neolithic date will be offered towards the end of this paper.

Expectations are also relevant. Barclay (2003: 142) has argued that modest and thus ephemeral hoe- or spade-cultivation was the norm, not animal-drawn ploughs, while field divisions could have been as simple as rickles of stones (Barclay 1985: 194; Barber 1997), light timber hurdles 
(Barclay 2003: 142-3), hedgerows (Loveday 2006: 113), or parcels of land left unworked and overgrown (after Bradley 2002: 91). None of these would leave much trace in the archaeological record. Ard marks are too ephemeral to contain artefacts securely, and almost always unsuitable for sourcing material for radiocarbon dating, and so most have been assigned a date based on form, proximity and/or termini quem relationships.

Reviews of evidence for physical traces of Neolithic farming in Scotland are often short on detail, and always brief (cf Kinnes 1985; Barclay 2003: 141-4; Guttmann 2005; Noble 2006: 37-40; ScARF 2012: section 4.1.2.4; Bishop 2015: 846-8). Kinnes (1985: 28-9), for instance, commented briefly on field systems across one paragraph, noting the lack of evidence for such features in mainland Scotland's Neolithic, but assuming their existence. More broadly, syntheses of prehistoric farming in Scotland (eg Halliday et al 1981; Lewis 2012) have shed light on a range of sites and practices that might be Neolithic in origin. The variety of techniques of arable farming used in prehistory, and associated material culture, are most clearly summarised in Fowler's The Farming of Prehistoric Britain (1981) which includes extensive discussion of different types of ploughs, ards and field boundaries which were utilised in prehistory, although precious few examples can be tied definitively to the Neolithic period.

Prompted by the SERF excavations, we have identified 27 sites across Scotland that through excavation have shown direct evidence for Neolithic agricultural practices with different degrees of probability (Table 1, and locations shown in Illus 8). For most of these sites dating is problematic, which is perhaps not a surprise given that even well-known 'Neolithic' field systems such as the Céide Fields complex, County Mayo, Ireland, continue to be the subject of debate in terms of how far back into prehistory they can be dated (contrast Whitefield 2017 with Caulfield et al 1997 and O'Connell et al 2020). Such chronological resolution also dogs the interpretation of agricultural remains from Shetland, the place in Scotland most closely associated with the infrastructure and practice of farming in prehistory. Reviews of the material from Shetland such as Calder (1956) and Turner (2013a) make clear that the quantity and nature of the evidence is in no doubt, with prehistoric stone and turf field banks, lynchets, enclosures and terraces, in some cases forming field systems, relatively commonplace. However, dating is a challenge (eg Barclay 2003). So, Turner (2013b) explored the agricultural practices indicated by such evidence but was unable to assign the vast majority of features to a particular period in prehistory. Excavations at Scord of Brouster and Sumburgh Airport have identified ard marks, stone field banks, cultivated soils and lynchets in close association with Neolithic buildings (Whittle et al 1986; Downes $\&$ Lamb 2000). However, detailed analysis of the chronological basis for such assumptions, and new survey work, recently led Christie (2020) to argue that most stone banks and buildings on Shetland are no earlier than the Bronze Age.

Aside from Shetland, possible field systems and boundaries have been identified almost wholly on west coast islands. A long-term farming landscape at Machrie Moor North, Arran, included stone bank-defined rectangular strip fields $200 \mathrm{~m}$ by $50 \mathrm{~m}$ in size; amid these, clearance cairns and possible cultivation ridges were also identified (Barber 1997: 144; Noble 2006: 37-8). These have been interpreted as Late Neolithic, but doubt has been shed on this (eg Taylor \& Hunter 2000: 185). 'Celtic fields' at Kilpatrick identified during the same programme of fieldwork through aerial photography were optimistically assigned to the Neolithic, although these have not been further investigated (Barber 1997: 144) and have not been included in our dataset. Traces of Neolithic field boundaries have also been found at Newton, Islay. Here, a group of linear grooves was identified, 'shallow features (c. $0.2 \mathrm{~m}$ wide, $0.25 \mathrm{~m}$ deep) ... cut in short lengths either running parallel to the terrace edge or across the terrace' (McCullagh 1989: 27). One of these, F27, had a kink similar to the hockey stick-shaped ditches found at Wellhill and Cranberry (Illus 9). These grooves were stratigraphically situated between a pit containing Neolithic pottery and a pit which produced a Late Neolithic radiocarbon date. The 
TABLE 1

Sites with evidence for potential Neolithic farming in Scotland discovered through excavation. Note that in most cases ard marks dates are certainly prehistoric, and only possibly Neolithic. None are dated directly, but rather by stratigraphy and/or spatial relationships. The sites are listed in alphabetical order, and locations shown in Figure 8

\begin{tabular}{|c|c|c|c|c|c|c|c|}
\hline \multirow[b]{2}{*}{ Site } & \multirow[b]{2}{*}{ Council area } & \multirow[b]{2}{*}{$N G R$} & \multicolumn{4}{|c|}{ Agricultural traces } & \multirow{2}{*}{$\begin{array}{l}\text { Reference } \\
\left({ }^{*} \text { means }\right. \\
\text { site has not } \\
\text { been fully } \\
\text { published } \\
\text { at time of } \\
\text { writing) }\end{array}$} \\
\hline & & & $\begin{array}{l}\text { Ard } \\
\text { mark }\end{array}$ & $\begin{array}{l}\text { Field } \\
\text { boundary }\end{array}$ & $\begin{array}{l}\text { Cultivation } \\
\text { ridge }\end{array}$ & $\begin{array}{l}\text { Soils } \\
\text { and } \\
\text { middens }\end{array}$ & \\
\hline $\begin{array}{l}\text { Allasdale } \\
\text { Dunes, Barra }\end{array}$ & Western Isles & $\begin{array}{l}\text { NF } 6563 \\
0285\end{array}$ & $x$ & & & $x$ & $\begin{array}{l}\text { Wessex } \\
\text { Archaeology } \\
2008^{*}\end{array}$ \\
\hline $\begin{array}{l}\text { Allt na Fearna } \\
\text { Mor (Achany } \\
\text { Glen) }\end{array}$ & Highland & NC 584019 & $x$ & & $x$ & $x$ & $\begin{array}{l}\text { McCullagh \& } \\
\text { Tipping } 1998\end{array}$ \\
\hline Arran WBH & North Ayrshire & $\begin{array}{l}\text { Should be } \\
\text { NS 0210 } \\
3530\end{array}$ & $x$ & $x$ & & & $\begin{array}{l}\text { Donnelly et al } \\
2000^{*}\end{array}$ \\
\hline Arran CTSA1 & North Ayrshire & $\begin{array}{l}\text { Should be } \\
\text { NR } 9280 \\
3310\end{array}$ & $x$ & & & & $\begin{array}{l}\text { Donnelly et al } \\
2000^{*}\end{array}$ \\
\hline $\begin{array}{l}\text { Biggar } \\
\text { Common }\end{array}$ & $\begin{array}{l}\text { South } \\
\text { Lanarkshire }\end{array}$ & NT 005385 & & & & $x$ & Johnson 1997 \\
\hline Calanais & Western Isles & $\begin{array}{l}\text { NB } 2130 \\
3302\end{array}$ & $x$ & & $x$ & & $\begin{array}{l}\text { Ashmore } \\
2016\end{array}$ \\
\hline Carn Dubh & $\begin{array}{l}\text { Perth and } \\
\text { Kinross }\end{array}$ & NN 976605 & $x$ & & & & Rideout 1996 \\
\hline Cranberry & $\begin{array}{l}\text { Perth \& } \\
\text { Kinross }\end{array}$ & $\begin{array}{l}\text { NO } 0113 \\
1415\end{array}$ & & $x$ & & & $\begin{array}{l}\text { Wright \& } \\
\text { Brophy in } \\
\text { prep* }\end{array}$ \\
\hline Halmie & Highland & \begin{tabular}{|l|} 
ND 1171 \\
3345 \\
\end{tabular} & $x$ & & & & $\begin{array}{l}\text { Morrison \& } \\
\text { Pollard 1994* }\end{array}$ \\
\hline $\begin{array}{l}\text { Knap of } \\
\text { Howar }\end{array}$ & Orkney & \begin{tabular}{|l|} 
HY 4830 \\
5180
\end{tabular} & & & & $x$ & Ritchie 1983 \\
\hline \begin{tabular}{|l} 
Links of \\
Noltland
\end{tabular} & Orkney & HY 428493 & $x$ & $x$ & & & $\begin{array}{l}\text { Clarke \& } \\
\text { Sharples } 1985\end{array}$ \\
\hline $\begin{array}{l}\text { Machrie Moor } \\
\text { North }\end{array}$ & North Ayrshire & NR 901348 & $x$ & $x$ & $x$ & & Barber 1997 \\
\hline $\begin{array}{l}\text { Machrie Moor } \\
1 \text { and } 11\end{array}$ & North Ayrshire & \begin{tabular}{|l|} 
NR 9121 \\
3243
\end{tabular} & $x$ & $x$ & & & $\begin{array}{l}\text { Haggarty } \\
1991\end{array}$ \\
\hline $\begin{array}{l}\text { Midmill } \\
\text { Industrial } \\
\text { Estate, Kintore }\end{array}$ & Aberdeenshire & $\begin{array}{l}\text { NJ } 3795 \\
8145\end{array}$ & $x$ & & & & $\begin{array}{l}\text { Murray \& } \\
\text { Murray } 2013\end{array}$ \\
\hline Newton, Islay & Argyll \& Bute & \begin{tabular}{|l|} 
NR 3412 \\
6283 \\
\end{tabular} & & $x$ & & & $\begin{array}{l}\text { McCullagh } \\
1989\end{array}$ \\
\hline Pitnacree & $\begin{array}{l}\text { Perth \& } \\
\text { Kinross }\end{array}$ & $\begin{array}{l}\text { NN } 9287 \\
5337\end{array}$ & & & & $x$ & $\begin{array}{l}\text { Coles \& } \\
\text { Simpson } \\
1965\end{array}$ \\
\hline
\end{tabular}


TABLE 1

Continued

\begin{tabular}{|c|c|c|c|c|c|c|c|}
\hline \multirow[b]{2}{*}{ Site } & \multirow[b]{2}{*}{ Council area } & \multirow[b]{2}{*}{$N G R$} & \multicolumn{4}{|c|}{ Agricultural traces } & \multirow{2}{*}{$\begin{array}{l}\text { Reference } \\
\text { (* means } \\
\text { site has not } \\
\text { been fully } \\
\text { published } \\
\text { at time of } \\
\text { writing) }\end{array}$} \\
\hline & & & $\begin{array}{l}\text { Ard } \\
\text { mark }\end{array}$ & $\begin{array}{l}\text { Field } \\
\text { boundary }\end{array}$ & $\begin{array}{l}\text { Cultivation } \\
\text { ridge }\end{array}$ & $\begin{array}{l}\text { Soils } \\
\text { and } \\
\text { middens }\end{array}$ & \\
\hline $\begin{array}{l}\text { North Mains } \\
\text { barrow }\end{array}$ & $\begin{array}{l}\text { Perth \& } \\
\text { Kinross }\end{array}$ & NN 926162 & & & $x$ & & Barclay 1983 \\
\hline $\begin{array}{l}\text { North Mains } \\
\text { henge }\end{array}$ & $\begin{array}{l}\text { Perth \& } \\
\text { Kinross }\end{array}$ & $\begin{array}{l}\text { NN } 9285 \\
1625\end{array}$ & & & & $\times$ & Barclay 1983 \\
\hline Pool, Sanday & Orkney & $\begin{array}{l}\text { HY } 6194 \\
3785\end{array}$ & $x$ & & & & Hunter 2007 \\
\hline $\begin{array}{l}\text { Scord of } \\
\text { Brouster }\end{array}$ & Shetland & $\begin{array}{l}\text { HU } 2560 \\
5165\end{array}$ & $x$ & $x$ & & $\times$ & $\begin{array}{l}\text { Whittle et al } \\
1986\end{array}$ \\
\hline $\begin{array}{l}\text { South Nesting } \\
\text { Hall }\end{array}$ & Shetland & HU 467535 & & & & $\times$ & $\begin{array}{l}\text { Dockrill et al } \\
1998\end{array}$ \\
\hline Sumburgh & Shetland & $\begin{array}{l}\text { HU } 3922 \\
1078\end{array}$ & $x$ & & & & $\begin{array}{l}\text { Downes \& } \\
\text { Lamb } 2000\end{array}$ \\
\hline Tofts Ness & Orkney & $\begin{array}{l}\text { HY } 7569 \\
4646\end{array}$ & $x$ & & & $\times$ & $\begin{array}{l}\text { Guttmann et } \\
\text { al } 2004\end{array}$ \\
\hline Upper Suisgill & Highland & NC 897251 & $\times$ & & & & Barclay 1985 \\
\hline Wester Hatton & Aberdeenshire & $\begin{array}{l}\text { NJ } 7967 \\
1458\end{array}$ & $x$ & & & & $\begin{array}{l}\text { Suddaby } \\
2015 ; \\
\text { Dingwall et al } \\
2019\end{array}$ \\
\hline $\begin{array}{l}\text { Vale Health } \\
\text { Centre, } \\
\text { Alexandria }\end{array}$ & $\begin{array}{l}\text { West } \\
\text { Dunbartonshire }\end{array}$ & NS 388806 & $x$ & & & & $\begin{array}{l}\text { Suddaby } \\
\text { forthcoming* }\end{array}$ \\
\hline Wellhill & $\begin{array}{l}\text { Perth \& } \\
\text { Kinross }\end{array}$ & $\begin{array}{l}\text { NO } 0225 \\
1571\end{array}$ & $\times$ & $\times$ & & & $\begin{array}{l}\text { Wright \& } \\
\text { Brophy in } \\
\text { prep* }\end{array}$ \\
\hline
\end{tabular}

grooves were interpreted as supports for flimsy fences, although the excavator was reluctant to see these as field boundaries (ibid: 48).

The presence of ard marks is - relatively speaking - more commonplace, although in almost all cases chronology is problematic. In some instances, excavators were unable to be any more precise than to affirm ard marks were prehistoric. Usually ephemeral and in criss-cross arrangements, there is some doubt as to how they were made and their function. A typical view is that ard marks were created by 'a tool with a wooden share which ripped turf and soil rather than turned it over' (Ashmore 2016: 9), elaborated as 'some sort of dragging process by animal or human traction' (Fowler \& Evans 1967: 290). It is thought that the tool used to make these marks would have been what could be described as a wooden 'bow ard' or scratch plough which could be operated by one person (Illus 10). Ard marks may indicate tillage, in other words ploughing to allow for the planting of crops. It has been argued, however, that due to their depth and the limited numbers they are usually found in, they evidence simply 'breaking-grassland' (Barclay 1985: 193) ahead of farming (Ashbee et al 1979: 282), or less likely preparing the ground for mound construction (Thomas 1999: 24; 
Height

$500 \mathrm{~m}$
$200 \mathrm{~m}$
$0 \mathrm{~m}$
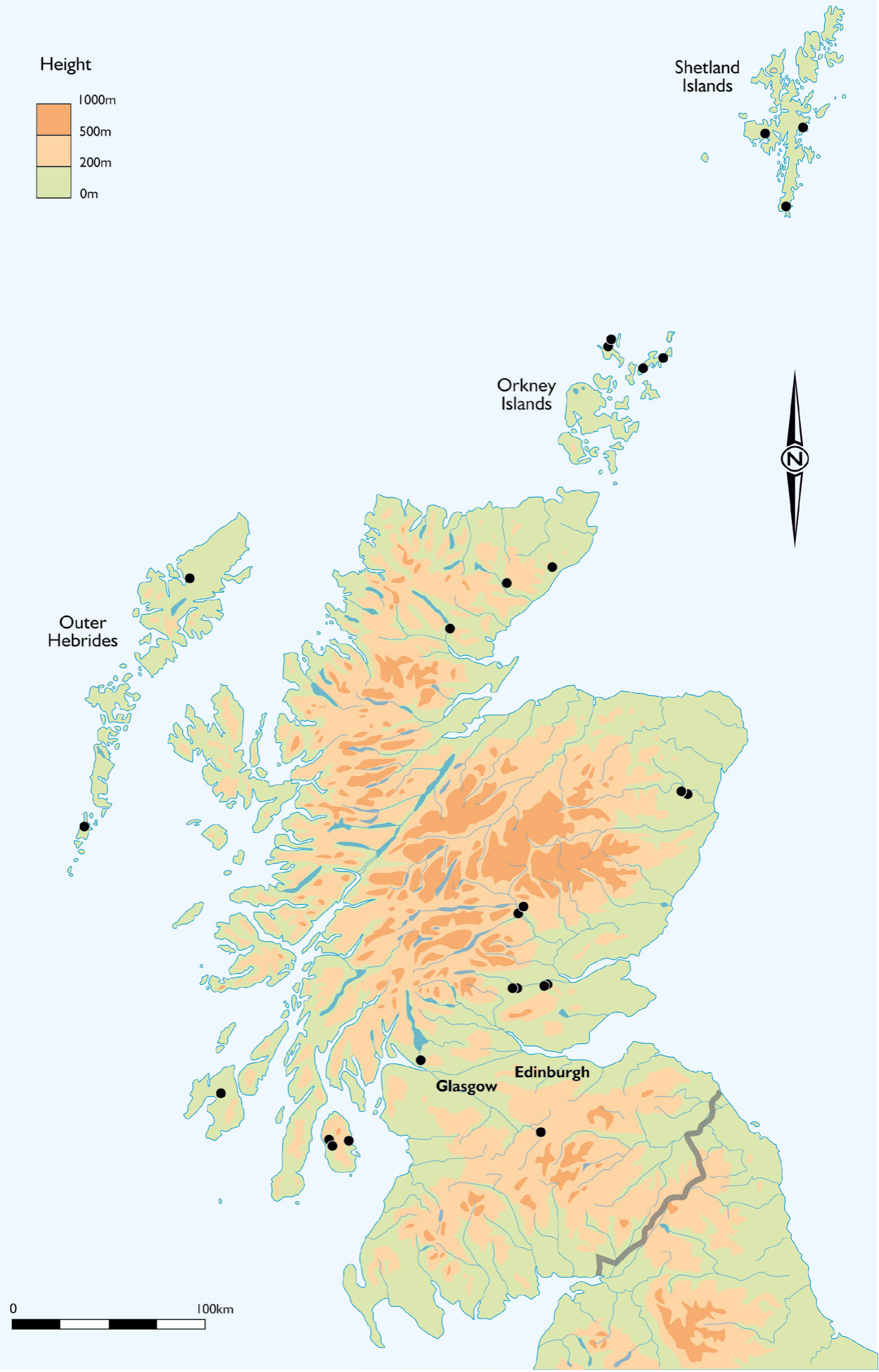

ILLus 8 Distribution of sites with evidence for possible Neolithic farming in Scotland identified through excavation. (Prepared by Lorraine McEwan) 


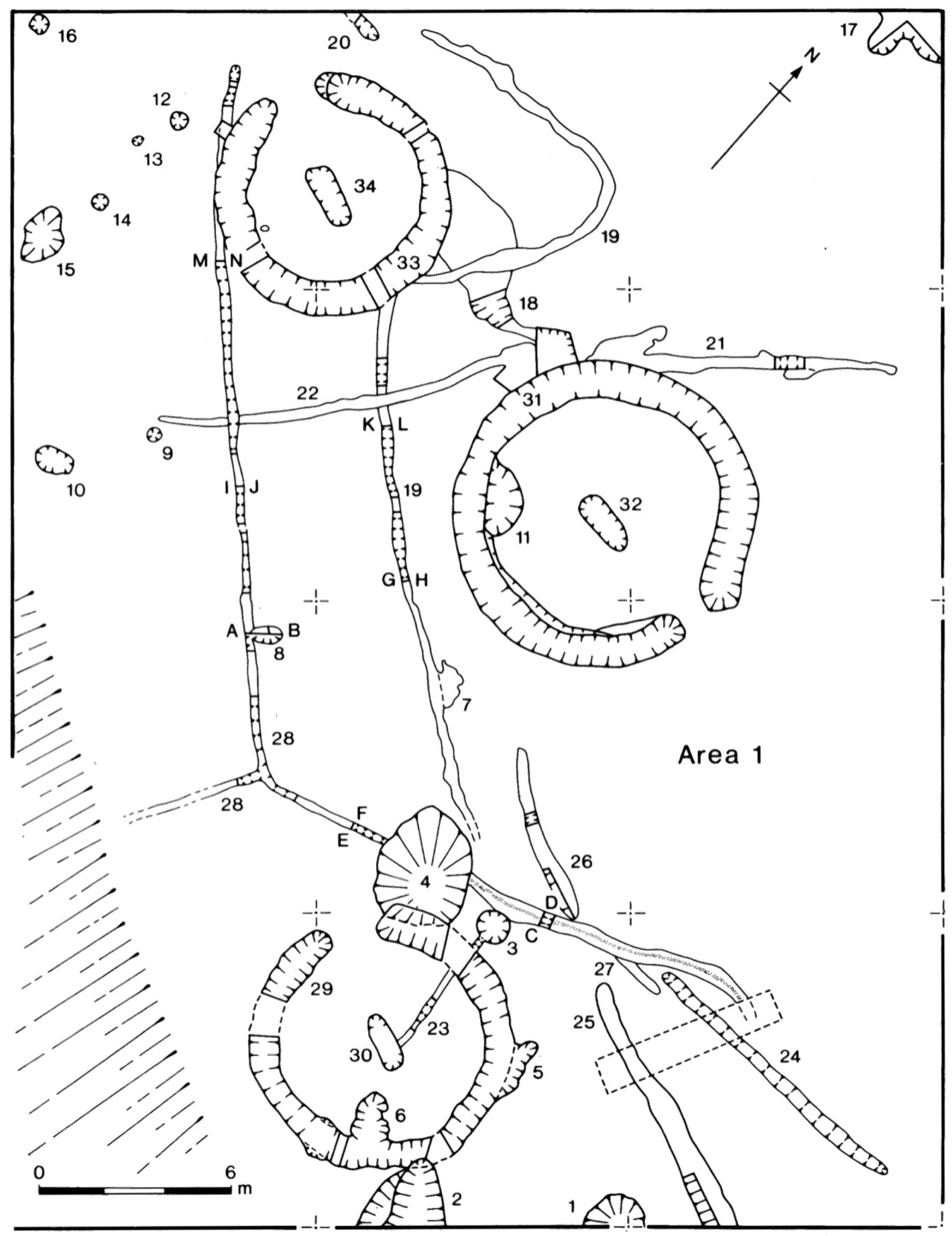

ILLus 9 Newton, Islay plan showing linear ditches, one with a kink in it (see number 28) similar to the features found at Wellhill and Cranberry. (From McCullagh 1989) 
2013: 400). To this end, Reynolds suggested that most ard marks represent such preparation of the ground with a larger 'rip-ard' rather than ploughing furrows for sowing seeds in, which would have been shallower and less likely to be evident in the archaeological record (Reynolds 1981).

At least three sets of ard marks have been found on Arran, two revealed during the Arran Ring Watermain pipeline evaluations, although at the time of writing both sites remain unpublished. One site, known as WBH, located south of Brodick, consisted of four groups of criss-crossing ard marks, none longer than $2 \mathrm{~m}$; these were found in close spatial association with a substantial ditch interpreted as a Neolithic field boundary, and a possible timber house (Donnelly et al 2000; Noble 2006: 38-9). A second site, CTSA2, was also found along the pipeline during a controlled topsoil strip; these were similarly sized ard marks across an area measuring $5 \mathrm{~m}$ by $14 \mathrm{~m}$, found in proximity to features associated with Neolithic pottery (Donnelly et al 2000). This site, located on the fringe of Machrie Moor, was near to where extensive ard marks were found pre-dating Stone Circles 1 and 11 on this moor; here, multiple phasing of marks suggested 'more than just an initial sod-breaking episode' (Haggarty 1991: 86) and these were found in association with a network of hurdle 'fences' and pits containing Impressed Ware potsherds (Illus 11). Together, the Arran discoveries suggest this island, as with Shetland, is a good location for future investigation into Neolithic farming.

Orkney is another island location with great potential with regards to physical evidence for farming practices. Ard marks dating to around 2700 BC were identified at Links of Noltland, Westray, in association with an apparent boundary ditch (Clarke \& Sharples 1985); some of the markings have been characterised by Barclay as spade marks (2003: 142). Ard marks were also found at Pool, Sanday, identified beneath a Neolithic midden (Hunter 2007) which may itself have been cultivated (Guttmann 2005: 232). At Tofts Ness, also Sanday, criss-crossing ard marks were found beneath cultivated soils of Neolithic date (Guttmann et al 2004).
Evidence for ard marks on the mainland is rare, with upland examples all clearly prehistoric, but only possibly Neolithic. At Achany Glen, Sutherland, multiple examples of ard marks, cultivation ridges and clearance cairns were found in association with Bronze Age settlement, with short, single-orientation ard marks interpreted as belonging to 'the third to second millennium cal BC' and made by a 'bow ard' (McCullagh \& Tipping 1998: 158-60). Barclay (1985) identified extensive ard tillage at Upper Suisgill, also Sutherland, stratigraphically earlier than an Iron Age roundhouse, some associated with possible spade marks. Deep in the site's sequence, 'no clue can be gained to the period over which the marks accumulated' (ibid: 193) but the excavator does not rule out a Neolithic date (G Barclay pers comm). At the complex Bronze Age Clavatype cairn, Halmie (Morrison \& Pollard 1994), ephemeral criss-cross ard marks of unknown date were identified beneath paving at the entrance to the Bronze Age central chamber. (This relationship has echoes in the discovery of ard marks beneath burial mounds.) Groups of ard marks identified beside Bronze Age roundhouses at Carn Dubh, Moulin, Perth and Kinross, are likely to be at least Early Bronze Age in age, if not earlier, due to stratigraphic relationships. The excavator suggested the 'use of this area for pasturage in the Neolithic and early Bronze Age' (Rideout 1996: 186), in part drawing on environmental evidence for woodland clearance (ibid: 182). These sites are all in locations outwith the arable plough zone, thus with a maximised chance of preservation but, even then, all also indicate the challenges of positively identifying Neolithic ploughing in the record.

Ard marks found in the lowland plough zone, almost all picked up through developer-funded excavations, are more challenging still. In 2012, ard marks were found in association with pits containing Grooved Ware in advance of construction of the Vale Health and Care Centre in Alexandria, West Dunbartonshire; here the criss-crossing ard marks had a terminus ante quem of the middle of the 3rd millennium cal BC (Suddaby forthcoming). Two areas of prehistoric ard marks, 


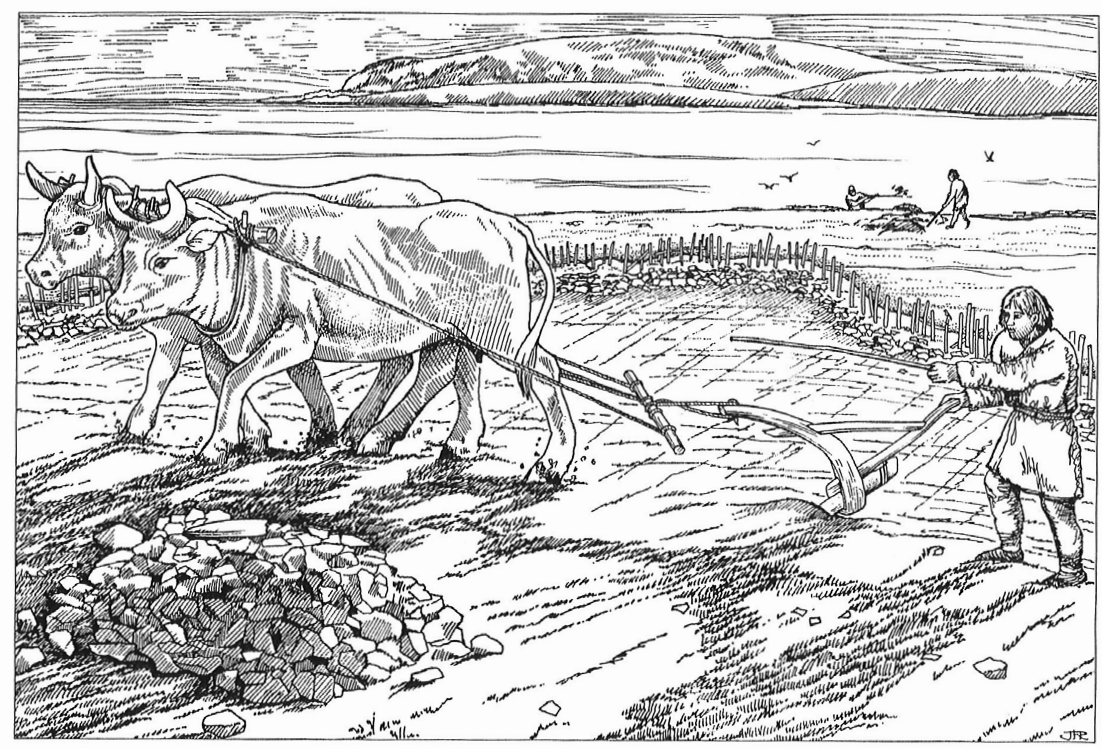

ILLus 10 Reconstruction drawing of animal-drawn ard ploughing in Shetland. (From Turner 1998: 25, artist Joanna Richards)

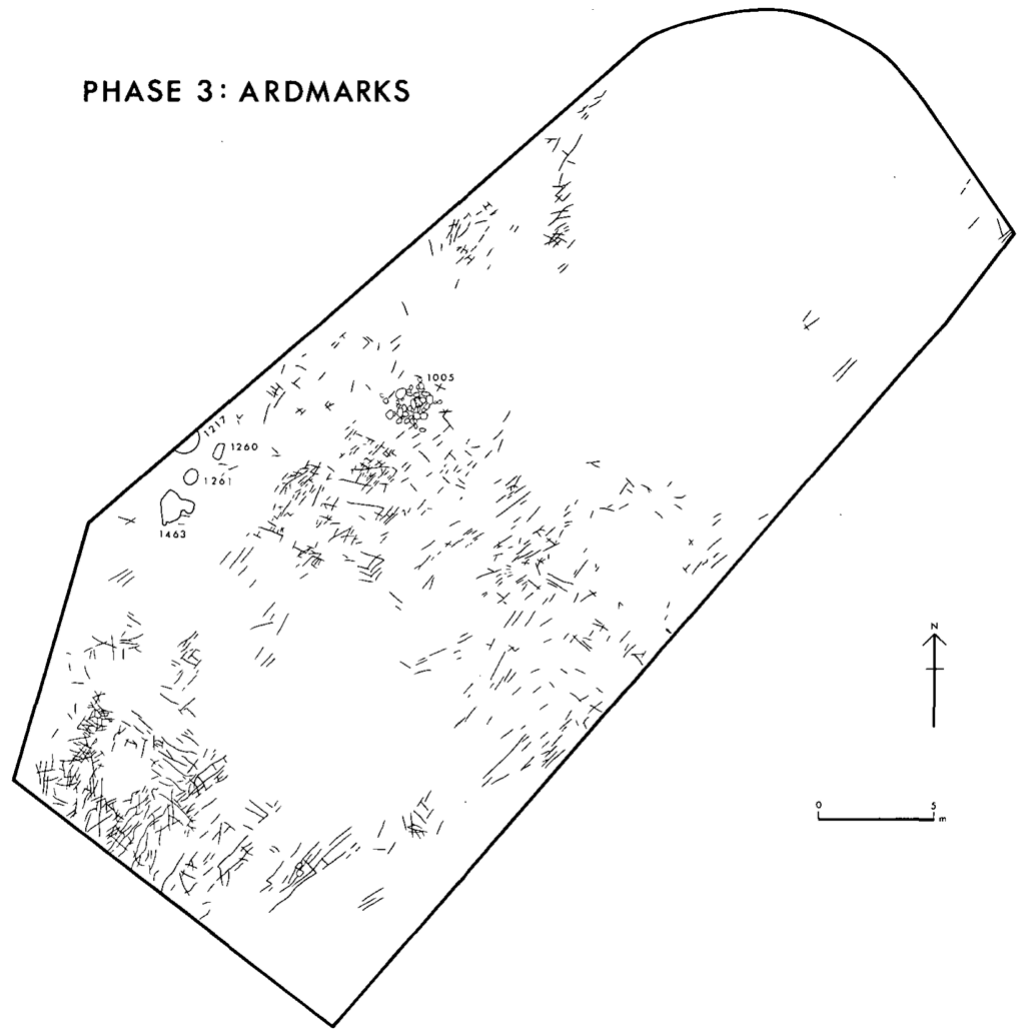

ILlus 11 Ard marks, Machrie Moor 1 and 11 that were identified in this location pre-dating two stone circles. (From Haggarty 1991, courtesy of the Society of Antiquaries of Scotland) 
some cutting pits containing Impressed Ware pottery, were identified before an industrial development at Kintore, Aberdeenshire (Murray \& Murray 2013), while criss-crossing ard marks were found at Wester Hatton in advance of the construction of the Aberdeen Western Peripheral Route, also in Aberdeenshire (Suddaby 2015). The date of the latter is unknown, but they were found in the vicinity of Neolithic pit clusters and a Bronze Age roundhouse settlement (Dingwall et al 2019). Such discoveries depend very much on serendipitous sampling of the landscape afforded by developer-funded archaeology, which may well be the main means of discovery of such features in the future.

Beyond ard marks, other physical traces of farming have been identified. At North Mains, Perth and Kinross, Barclay recorded what he called cultivation ridges beneath a Bronze Age earthen barrow: they were 'a maximum of $0.15 \mathrm{~m}$ high and measured 1.8 to $2 \mathrm{~m}$ from crest to crest' (1983: 191). Barclay (1989) drew parallels between these and later cord rig farming, and observed that some ridges were almost impossible to photograph and challenging to record, as was the case with the Wellhill ard marks. Similar cultivation 'beds' were also identified at Calanais, Western Isles, dating to around $3000 \mathrm{BC}$ and consisting of regular undulations created by spade or hoe cultivation (Ashmore 2016). Ephemeral traces of farming were found beneath North Mains henge, adjacent to the barrow: 'the disturbance of the fossil soil to a depth of $0.12 \mathrm{~m}$ as demonstrated by clay translocation may be the result of ard cultivation' while 'gleyed fossil topsoil may have been formed by the activity of stock' (Barclay 1983: 180; and see also Romans \& Robertson 1983). At Pitnacree, also Perth and Kinross, the excavators identified unusually deep and well-sorted soils beneath the Neolithic barrow which they interpreted as having been cultivated (Coles \& Simpson 1965). Possible cultivated or at least 'disturbed' soils of Neolithic date were found beneath a cairn at Biggar Common, South Lanarkshire (Johnson 1997; Bishop 2015: 847), a rare example in southern Scotland - like Arran WBH and Machrie Moor North - of farming found in proximity to a putative Neolithic house.
A range of sites with soil micromorphological evidence for 'soil amendment practices' indicative of cultivation of 'permanently managed plots' have been found from Late Neolithic Orkney (cf Bishop 2015: 847). Guttmann (2005; and see Guttmann et al 2004) has collated such a series of sites in the Northern Isles where evidence for organic midden material, domestic refuse and/or peat ash being used as fertiliser has been picked up in soils. This includes sites such as the Knap of Howar, Orkney, where 'Neolithic soils rich in midden material were spread out over an area of c. $500 \mathrm{~m}^{2}$, possibly for cultivation' (Guttmann 2005: 231; Ritchie 1983), and Scord of Brouster where soil containing peat ash was documented (Romans 1986; Whittle et al 1986). Guttmann has also identified evidence for middens that were cultivated in prehistory, in Shetland, at Old Scatness, and Tofts Ness on Orkney (Guttmann 2005: 231-2; and see Simpson et al 1998; Guttmann et al 2004). This cultivation technique, found in association with ard marks at both of these sites, was occurring in the Bronze Age, but it seems likely that this was also a Neolithic practice in the Northern Isles, at Pool for instance. Such 'anthropogenic soils' have also been identified for the Late Neolithic at Jarlshof, Shetland, and Dockrill \& Bond (1999) argued that at such sites small 'midden-rich arable plots' were formed through the addition of carbonised material from seeds to animal and bird bones. Similar evidence, cultivated soils with an organic midden element, cut by ard marks, was found beneath a mound during evaluation at Allasdale Dunes, Barra. The date was unclear but the excavators argued that 'this episode of ploughing could ... be late Neolithic' (Wessex Archaeology 2008: 26) and it was found close to a Late Neolithic or Early Bronze Age roundhouse.

\section{THE BIGGER PICTURE}

Can we learn from evidence and approaches to Neolithic farming practice elsewhere? Broadly similar types of evidence for ploughing and fields have been found across the rest of Britain, equally sporadically. However, current overviews of the 
British Neolithic have little to say on this subject, suggesting that our narratives of what it was to be an early farmer still have some way to go on the physical act of farming. In part of course this is due to the lack of evidence. Darvill (2010: 90-2) focuses on proxy evidence for crops and cultivation for the most part but notes the discovery beneath several long barrows in southern England of 'traces of ploughing in the form of criss-cross grooves' (ibid: 91). This includes the classic example of South Street long barrow, Wiltshire, where simple ard ploughing was followed by a period of pasturage, then barrow construction (Ashbee et al 1979; Fowler 1981: 114-16). These marks were dated to the 36th century cal BC (Evans 1971; and see Thomas 1999: 24). Cummings (2017) devotes less than two paragraphs to the evidence across her book exploring the Neolithic of Britain and Ireland, mentioning only Céide Fields (Ireland) and South Street barrow.

Ray \& Thomas's 2018 book Neolithic Britain: The Transformation of Social Worlds also has very little to say on the physical process of farming. In the index, there is no entry for 'farming', but 'farmer' is to be found on 12 pages. In each instance this term is used to generically describe Neolithic people: they were farmers. 'Ard' appears once in the main text of the book, the ard ploughing that preceded the construction of South Street barrow noted as an 'interesting feature' (ibid: 118), a footnote in a mortuary and monumentality narrative. ('Ard' does, however, appear in the glossary of terms in this book (ibid: 318).) Elsewhere, Thomas (2013: 399-400) has argued that ard marks are rare perhaps because 'the use of the plough was sporadic or absent during the Neolithic' outwith the Northern Isles of Scotland. However, this kind of argument has been gradually dismantled in the past two decades in relation to Neolithic houses in the British mainland (cf Bradley 2019: 32) and there is no reason to suppose that the absence of evidence does indicate evidence for absence.

There are other examples beyond South Street, with land divisions and field boundaries found at Fengate, Cambridgeshire, some of which are of potentially Neolithic date (Pryor 2005), while ard marks and cultivated soils were identified beneath Hazelton North long barrow, Gloucestershire (Macphail 1990; Guttmann 2005: 231). Earlier reviews of such limited evidence raised the enduring problem of dating boundaries, plough scrapes and lynchets (Fowler \& Evans 1967; Smith \& Evans 1968) making 'sealed' ard marks such as those found under aforementioned barrows, but also Amesbury G71, Wiltshire, and Kilham, Yorkshire (Darvill 2010: 92), so valuable. More recently there has been a growing focus on big data and multidisciplinary approaches on the proxies for farming (Jones \& Rowley-Conwy 2007; Bishop et al 2009; Treasure et al 2020; Rowley-Conwy et al 2020), with physical traces remaining rare discoveries that await synthesis.

Much valuable work has been undertaken on farming proxies and the farming economy across north-western Europe, with an established body of literature on aspects of Neolithic farming (such as Kristiansen 2001; Bogaard 2005; Bogaard \& Jones 2007). For instance, exciting synthetic work has been done on the chronology, environment and farming economy in Ireland through the Cultivating Societies project (eg Whitehouse et al 2014; McClatchie et al 2016, 2019) but little of this attention has thus far been focused on the physical act of farming. However, authors of these studies have ventured that Ireland's Neolithic farming was at a 'fixed-plot intensive garden agricultural' level (McClatchie et al 2016: 316), echoing observations made for this period elsewhere in Britain and mainland Europe (eg Bogaard \& Jones 2007; Bishop et al 2009). But what was happening in these plots?

There are instances of ard marks, cultivated soils, field systems and other indicators of farming activity across north-west Europe, some of which are closely similar in nature to the evidence from Britain. For instance, ard marks have been identified at Neolithic sites in the Netherlands including Hellovoetsluis-Ossenhoek (Goossens 2009) and Zeewijk East (Nobles 2014), and tillage marks, probably made by a hoe, in combination with cultivated soils, were identified at Swifterbant site S4 (Huisman \& Raemaekers 
2014: 581). In Denmark, possible Neolithic ard marks have been documented at Højensvej and Flintbek 3 (Mischka 2011; Sørensen 2014). As in Scotland, this work has been hampered by a lack of chronological detail, and for the most part archaeological science has taken the lead in exploring traces of farming.

\section{IMPLICATIONS FOR OUR UNDERSTANDING OF NEOLITHIC FARMING IN SCOTLAND}

\section{IDENTIFYING TRACES OF NEOLITHIC FARMING}

Bishop (2015: 847) has argued that, outwith urban and built-up areas, 'traces of cultivation only survive beneath later undisturbed archaeological activity', yet our discoveries at Wellhill and Cranberry potentially counter this claim. Such features not beneath a protecting mound, structure or peat are indeed very rare but not, as we have argued, unknown. A contributing factor in the identification of the ard marks at Wellhill may well have been what the farmer had been doing: a regime long adopted in this field of setaside, and no history of deep ploughing, which is unusual in this region of premium grade agricultural soils. Fields with such histories are more likely to preserve ard marks, and so it is worth asking farmers and landowners for such information ahead of excavations.

The location of Wellhill on gravel subsoils, as with most of mainland lowland Scotland, explains the difficulty of photographing, drawing and excavating ard marks; these features dropped in and out of visibility depending on time of day and atmospheric moisture levels and at times appeared to be little more than a slight colour change in what was assumed to be the natural. This is a well-recognised phenomenon of digging in the gravels of northern Britain (cf Dingwall et al 2019: 329-31). In such surface geological conditions, we recommend checking for ard marks on site first thing in the morning and as the site dries after rain. Developer-funded discoveries in Scotland, all since 2008, suggest that ard marks in lowland mainland Scotland are not as rare as one might imagine; it is perhaps a matter of altering expectations and remaining vigilant when digging on gravels.

Much more can be done in terms of identifying other types of remains of farming. The work of Guttmann (2005) shows that the enrichment of soils with organic and peat ash components and cultivated middens were probably Neolithic practices in Scotland. By its nature such evidence is much more likely to be found in the sealed deep deposits found on long-lived domestic sites in the Northern and Western Isles. However, the presence of 'hearth-sweepings' of Neolithic date within recuts into Mesolithic pits at Wellhill could indicate that a soil enrichment strategy was played out in this location; perhaps we should re-evaluate how we interpret deposits within some Neolithic pits (Brophy \& Noble 2011). The identification of cultivated soils, and their analysis, has great potential, with for instance experimental micromorphological work in Scotland on this topic to date looking promising (eg Davidson \& Carter 1998, 2003; see also Macphail et al 1990). This is another potential aspect of our sampling and analysis toolkit in certain circumstances.

Interpretations of excavation and environmental results which show awareness of the possibility of crop and animal husbandry are also to be encouraged, such as the identification of seaweed foddering and goat faecal pellet manuring practices at an Early Neolithic settlement site at Maybole, South Ayrshire (Becket \& MacGregor 2009) and the recognition of seaweed-eating sheep at Skara Brae, Orkney (Balasse et al 2019). It is clear that newly developed, or applied, techniques can also shed light on issues related to farming practice and soils, including plant and soil ancient DNA (aDNA) (eg Parducci et al 2017), stable isotope analysis (eg Treasure et al 2020), and the analysis of coprostanols (eg Romaniuk et al 2020). As noted above, we also need to re-assess our preconceptions when it comes to interpreting upland earthworks and cropmark evidence in order to potentially broaden the evidential base. 


\section{INTERPRETING TRACES OF NEOLITHIC} FARMING

Barclay (2003: 148) argued that low-level agricultural practice in Early Neolithic Scotland was the norm, based on 'hoe- and spade-, if not ard-cultivated plots ...; the organization, sizes and boundary structures of such plots or fields might vary widely ...; pasture was managed and enclosed'. This seems reasonable when tested against the evidence reviewed in this paper. We would argue, however, that Kinnes (1985: 28) was over-optimistic in his assertion that 'the evidence suggests that agriculturally favourable areas at least had assumed a familiar landscape pattern within the first few hundred years of established farming: organised fields, farmsteads and controlled woodland reserves.' On the other hand, Thomas (1999: 25) was too pessimistic with his assessment that Neolithic farmers should not be characterised as 'tied to their fields' because in effect there were no fields to be tied to (and see also Thomas 2013). The evidence to date suggests a middle ground where tilling of the land was part of a 'garden agriculture' strategy (eg Bogaard 2005; Bogaard \& Jones 2007; Whitehouse et al 2014), perhaps practised within a framework of transhumance mobility (Brophy 2006).

There is limited evidence for the repeat ploughing of the same location over multiple seasons, with examples of extensive and repeated scraping of the land as found at Machrie Moor and South Street being rare. Even in the latter case, Fowler (1981: 116) suggests that perhaps only five different episodes of ploughing were identifiable. This may simply relate to the rarity and/or ephemerality of the evidence, or perhaps these are indeed the traces of one-off events for land preparation (Reynolds 1981; Thomas 2013: 399-400). Ard marks do not tend to shed much light on how people were tethered to one location, in other words, and the general lack of spatial coincidence between farming activity and Neolithic houses seems to support this suspicion. The same spots may not have been chosen for growing crops year after year as we perhaps assume would need to be the case. It is also possible that growing cereals may have been a more prominent activity in the earlier Neolithic, with Stevens \& Fuller (2012) suggesting that this practice declined after $3300 \mathrm{BC}$, and so the evidential basis for ard ploughing and so on may have been compressed into a few centuries.

As well as issues of temporality, we should consider the symbolic as well as the practical aspect of this transformative activity (eg Farrington \& Urry 1985; Hodder 1990; Thomas 1999). There are, for instance, obvious parallels with scarification, which it is possible was a practice in prehistory, while the recurring, almost monotonous, cutting of the land is reminiscent of the repetitive actions inherent in other aspects of Neolithic life such as axe polishing, using querns to process cereals and creating rock art. We should perhaps see ploughing as an aspect of a suite of meditative, even self-healing, strategies, adopted by early farmers identified by Telford (2019) as potentially stemming from the 'transition trauma' of Neolithicisation. Farming also allowed the production and consumption of new foodstuffs, which it has been suggested were tied in with emerging identity and cultural tradition (Thomas 2013; McClatchie et al 2019). The act of farming made this cultural transformation possible; this conjures the notion of ploughing as a socio-political act.

It is interesting that the ard marks at Wellhill were in a location already marked by an ancient Mesolithic pit-alignment. Environmental evidence from those features suggests that they sat in a semi-open setting, and it could be argued that the history of this place and its open tree coverage made this locale an attractive proposition for early farmers. Mesolithic activity was also identified at Newton, Islay, and a very early Neolithic timber hall was constructed just $140 \mathrm{~m}$ from the Crathes Mesolithic pit-alignment. On this basis it could be argued that acts associated with new farming practices were deliberately carried out at ancient (or ancestral) places, whether that be building monuments, depositing ceramics - or tilling the land. Darvill (2010: 81) has noted an apparent interest among early farmers in hunter-gatherer places of significance. It could be argued, more tenuously, that materials dug from 
the ancient hollows indicating the Wellhill pits may have been used symbolically to fertilise these new fields with the very stuff of the ancestors. Midden material, and domestic waste, when put back into these holes, could be read as some kind of ancestral transaction perhaps associated with hopes for crop success, although we acknowledge that this stretches the evidence further than some would be comfortable with. Thomas (1999: 63) has described this kind of practice as the deposition of 'symbolic manure'.

The modest discoveries at Wellhill and Cranberry may offer a tantalising glimpse of a radically new practice introduced into the landscape of eastern lowland Scotland in the Neolithic period. Should these possible farming traces date back to this time, they would be unusually early direct physical evidence for this activity carried out by people from among the first few generations of farmers (Whittle et al 2011: 838-40). In this context, by establishing a new way of life, the act of farming is likely to have been a means for the transformation of places within a new cultural tradition, not merely facilitating the growth of entirely new foodstuffs.

\section{CONCLUSION}

In this paper we have raised the challenges and opportunities associated with the identification, dating and interpretation of the physical traces of Neolithic farming practice. From plough scrapes to field divisions, evidence remains sparse in relation to a much broader body of work and data derived from scientific analyses. Yet we would argue that there is much merit in revisiting the tangible evidence we have for the practice of managing domesticates by the first farmers in Scotland, and beyond, and in doing this we have raised awareness of the forms and places such evidence might be found.

It remains a source of surprise to us how little consideration has been given in Neolithic studies to the significance, materiality, directionality and performative aspects of being a farmer at this time, in particular of being a farmer in a landscape where people had never farmed before.
With the central role that farming played in the lifeway of being Neolithic, surely this phenomenon deserves to play a fuller role in our narratives of the period? We would suggest that this requires a re-evaluation of the nature of the evidence that we have, the development of strategies to maximise the recognition of relevant evidence in the future, and a reconsideration of the role that the physical practice of farming had in Neolithic society and its impact on the land.

To do this, more research is required into the evidence we have for Neolithic fields, ploughing and tilling the land, and it is likely that further data will emerge from a trawl through the mass of grey literature. More thought must be given to the recurrence of sealed outcomes of agricultural practice beneath mounds: to what extent is this a product of archaeological bias? If not, then what is the significance? Our field survey and excavation strategies need to include at least the expectation of the possibility of farming evidence surviving even in the most unlikely of places. It is time for a broad reconsideration of the strategic and symbolic significance of scraping a plough across the surface of the land and how that helped to establish a new way of life across Scotland and beyond.

\section{ACKNOWLEDGEMENTS}

The excavations at Wellhill and Cranberry were sponsored by Historic Environment Scotland (HES, formerly Historic Scotland) and supported by the University of Glasgow. HES also grantaided this publication to ensure open access. We would like to thank David Myles for allowing us to excavate at Wellhill and giving us ploughing history information; permission to excavate at Cranberry was given by Calum Rollo and John Neil. Site supervisors were Jamie Barnes and Cathy MacIver. Radiocarbon dates for Wellhill were analysed by Derek Hamilton, the ceramic assemblage by Alex Alexander, and botanical analysis undertaken by Susan Ramsey; thanks to all for their input into this paper. We are grateful to Beverley Ballin Smith, Iain Banks, Kirsty Dingwall, Mel Johnson, Hilary Murray, Tony 
Pollard and Ian Suddaby for providing us with, and allowing us to use, information related to as-yet unpublished sites. Illus 1, 3, 4, 6 and 8 were prepared by Lorraine McEwan. Illus 2 is reproduced with permission from HES. Early drafts of this paper were commented on by Gordon Barclay, Ewan Campbell and Michael Given, and we are very grateful for their insights which strengthened the paper considerably. This final version of the paper very much benefited from the comments and insight of two anonymous referees. Finally, we would like to thank everyone who worked on the SERF excavations discussed above, and for the support of our colleagues in the SERF Project - Ewan Campbell, Stephen Driscoll, Gordon Noble and Tessa Poller.

\section{REFERENCES}

Alexander, A, Brophy, K \& Wright, D in prep 'An integrated approach to Neolithic pottery in Scotland: analysis of assemblages from Leadketty, Wellhill, Cranberry and Dun Knock', Scottish Archaeological Internet Reports.

Anderson-Whymark, H \& Thomas, J (eds) 2011 Beyond the Mundane: Regional Perspectives on Neolithic Pit Deposition. Oxford: Oxbow Books.

Ashbee, P, Smith, I F \& Evans, J G 1979 'Excavation of three long barrows near Avebury, Wilts.', Proceedings of the Prehistoric Society 45: 207-300.

Ashmore, P 2016 Calanais Survey and Excavation, 1979-88. Edinburgh: Historic Environment Scotland.

Balasse, M, Tresset, A, Obein, G, Fiorillo, D \& Gandois, H 2019 'Seaweed-eating sheep and the adaptation of husbandry in Neolithic Orkney: new insights from Skara Brae', Antiquity 93: 919-32.

Barber, J (ed) 1997 The Archaeological Investigation of a Prehistoric Landscape: Excavations on Arran 1978-81. Edinburgh: Scottish Trust for Archaeological Research.

Barclay, G J 1983 'Sites of the third millennium $\mathrm{BC}$ to the first millennium AD at North Mains,
Strathallan, Perthshire', Proc Soc Antiq Scot 113: 122-281.

Barclay, G J 1985 'Excavations at Upper Suisgill, Sutherland', Proc Soc Antiq Scot 115: 159-98.

Barclay, G J 1989 'The cultivation remains beneath the North Mains, Strathallan, barrow', Proc Soc Antiq Scot 119: 59-61.

Barclay, G J 2003 'The Neolithic', in Edwards, K \& Ralston, I B M (eds) Scotland after the Ice Age, 127-49. Edinburgh: Edinburgh University Press.

Becket, A \& MacGregor, G 2009 'Forest grazing and seaweed foddering: early Neolithic occupation at Maybole, South Ayrshire', Proc Soc Antiq Scot 139, 105-22.

Becket, A \& MacGregor, G 2011 'Big pit, little pit, big pit, little pit ... Pit practices in western Scotland in the 4th millennium BC', in Anderson-Whymark, H \& Thomas, J (eds) Regional Perspectives on Neolithic Pitdigging: Beyond the Mundane, 51-62. Oxford: Oxbow Books.

Bishop, R 2015 'Did Late Neolithic farming fail or flourish? A Scottish perspective on the evidence for Late Neolithic arable cultivation in the British Isles', World Archaeology 47: 834-55.

Bishop, R R, Church, M J \& Rowley-Conwy, P A 2009 'Cereals, fruits and nuts in the Scottish Neolithic', Proc Soc Antiq Scot 139: 47-103.

Bogaard, A 2005 “ "Garden agriculture” and the nature of early farming in Europe and the Near East', World Archaeology 37(2): 177-96.

Bogaard, A \& Jones, G 2007 Neolithic farming in Britain and central Europe: contrast or continuity? in Whittle, A \& Cummings, V (eds) Going Over: The Mesolithic-Neolithic Transition in North-West Europe, 357-75. London: British Academy.

Bradley, R 2002 The Past in Prehistoric Societies. London: Routledge.

Bradley, R 2019 The Prehistory of Britain and Ireland. Cambridge: Cambridge University Press.

Brophy, K 2006 'Rethinking Scotland's Neolithic: combining circumstance and context', Proc Soc Antiq Scot 136: 7-46.

Brophy, K \& Noble, G 2011 'Within and beyond pits: deposition in lowland Neolithic Scotland', 
in Anderson-Whymark, H \& Thomas, J (eds) Beyond the Mundane: Regional Perspectives on Neolithic Pit Deposition, 63-76. Oxford: Oxbow Books.

Brophy, K \& Noble, G 2020 Prehistoric Forteviot: Excavations of a Ceremonial Complex in Eastern Scotland. York: Council for British Archaeology (SERF Project Monograph 1).

Calder, C S T 1956 'Report on the discovery of numerous house-sites in Shetland', Proc Soc Antiq Scot 89: 340-97.

Caulfield, S, O’Donnell, R \& Mitchell, P 1997 'C14 dating of a Neolithic field system at Céide Fields, County Mayo, Ireland', Radiocarbon 40(2): 629-40.

Christie, C 2020 'Farming on the Edge: Towards an Understanding of the First Farming Societies of Shetland', unpublished $\mathrm{PhD}$ thesis, University of Aberdeen.

Clarke, D V \& Sharples, N 1985 'Settlement and subsistence in the third millennium BC', in Renfrew, C (ed) The Prehistory of Orkney, 286-305. Edinburgh: Edinburgh University Press.

Coles, J M \& Simpson, D D A 1965 'The excavation of a Neolithic round barrow at Pitnacree, Perthshire, Scotland', Proceedings of the Prehistoric Society 31: 34-57.

Cummings, V 2017 The Neolithic of Britain and Ireland. London: Routledge.

Darvill, T 2010 Prehistoric Britain. London: Routledge.

Davidson, D D \& Carter, S P 1998

'Micromorphological evidence of past agricultural practices in cultivated soils: the impact of a traditional agricultural system on soils in Papa Stour, Shetland', Journal of Archaeological Science 25: 827-38.

Davidson, D D \& Carter, S P 2003 'Soils and their evolution', in Edwards, K J \& Ralston, I B M (eds) Scotland after the Ice Age: Environment, Archaeology and History 8000 BC-AD 1000, 45-62. Edinburgh: Edinburgh University Press.

Dingwall, K, Ginnever, M, Tipping, R, Van Wessel, J \& Wilson, D 2019 The Land Was Forever: 15,000 Years in North-East Scotland. Oxford: Oxbow Books.

Dockrill, S \& Bond, J 1999 'Sustainability and resilience in prehistoric North Atlantic Britain: the importance of a mixed palaeoeconomic system', Journal of the North Atlantic 2(1): 33-55.

Dockrill, S, Bond, J \& O'Connor, T P 1998

'Beyond the burnt mound: the South Nesting palaeo landscape project', in Turner, V (ed) The Shaping of Shetland, 61-85. Lerwick: The Shetland Times.

Donnelly, M, McLellan, K \& Sneddon, D 2000 'Arran Ring Main Water Pipeline', unpublished Glasgow University Archaeological Research Division (GUARD) report, University of Glasgow.

Downes, J M \& Lamb, R 2000 Prehistoric Houses at Sumburgh in Shetland: Excavations at Sumburgh Airport 1967-74. Oxford: Oxbow Books.

Driscoll, S T, Brophy, K \& Noble, G 2010 'The Strathearn Environs and Royal Forteviot Project (SERF)', Antiquity Project Gallery 84. https:/antiquity.ac.uk/projgall/driscoll323/ Accessed 27 March 2018.

Evans, C 1971 'Habitat change on the calcareous soils of Britain: the impact of Neolithic man', in Simpson, D D A (ed) Settlement and Economy in Neolithic and Early Bronze Age Britain and Europe, 27-73. Leicester: Leicester University Press.

Farrington, I \& Urry, J 1985 'Food and the early history of cultivation', Journal of Ethnobiology 5: $143-57$.

Fowler, P J 1981 The Farming of Prehistoric Britain. Cambridge: Cambridge University Press.

Fowler, P J \& Evans, J G 1967 'Plough marks, lynchets and early fields', Antiquity 41: 289-301.

Goossens, T A 2009 Opgraving HellevoetsluisOssenhoek. Een nederzettting van de Vlaardingen-groep op een kwelderrug in de gemeente Hellevoetsluis (Archol-rapport, 87). Leiden.

Guttmann, E B A 2005 'Midden cultivation in prehistoric Britain: arable crops in gardens', World Archaeology 37: 224-39.

Guttmann, E B A, Dockrill, S J \& Simpson, I A 2004 'Arable agriculture in prehistory: new evidence from soils in the Northern Isles', Proc Soc Antiq Scot 134: 53-64. 
Haggarty, A 1991 'Machrie Moor, Arran: recent excavations at two stone circles', Proc Soc Antiq Scot 121: 51-94.

Halliday, S P, Hill, P J \& Stevenson, J N 1981 'Early agriculture in Scotland', in Mercer, R (ed) Farming Practice in British Prehistory, 55-65. Edinburgh: Edinburgh University Press.

Hodder, I 1990 The Domestication of Europe: Structure and Contingency in Neolithic Societies. Oxford: Basil Blackwell.

Huisman, D J \& Raemaekers, R C M 2014 'Systematic cultivation of the Swifterband wetlands (The Netherlands): evidence from Neolithic tillage marks (c. $4300-4000 \mathrm{cal}$ BC), Journal of Archaeological Science 49: 572-84.

Hunter, J 2007 Investigations in Sanday, Orkney: Excavations at Pool, Sanday - a Multiperiod Settlement from Neolithic to Late Norse Times, vol 1. Kirkwall: The Orcadian and Historic Scotland.

Johnson, D A 1997 'Biggar Common, 1987-93: an early prehistoric funerary and domestic landscape in Clydesdale, South Lanarkshire', Proc Soc Antiq Scot 127: 185-253.

Jones, G E M \& Rowley-Conwy, P 2007 'On the importance of cereal cultivation in the British Neolithic', in Colledge, S \& Conolly (eds) J The Origin and Spread of Domestic Plants in Southwest Asia and Europe, 391-419. London: University College London Institute of Archaeology Publications.

Kinnes, I 1985 'Circumstance not context: the Neolithic of Scotland as seen from the outside', Proc Soc Antiq Scot 115: 15-57.

Kristiansen, S M 2001 'Present-day soil distribution explained by prehistoric land-use: Podzol-Arenosol variation in ancient woodland in Denmark', Geoderma 103: 273-89.

Lewis, H 2012 Investigating Ancient Tillage: An Experimental and Soil Micromorphological Study. Oxford: Archaeopress.

Loveday, R 2006 Inscribed across the Landscape: The Cursus Enigma. Stroud: Tempus.

Loveday, R 2016 'Hiatus or hidden? The problem of the missing Scottish upland cursus monuments', in Brophy, K, MacGregor, G \& Ralston, I (eds) The Neolithic of Mainland
Scotland, 97-115. Edinburgh: Edinburgh

University Press.

McClatchie, M, Bogaard, A, Colledge, S, Whitehouse, N J, Schulting, R J, Barratt, P \& McLaughlin, T R 2016 'Farming and foraging in Neolithic Ireland: an archaeobotanical perspective', Antiquity 90: 302-18.

McClatchie, M, Schulting, R J, McLaughlin, T R, Colledge, S, Bogaard, A, Barratt, P \& Whitehouse, N J 2019 'Food production: processing and foodways in Neolithic Ireland', Environmental Archaeology DOI: 10.1080/14614103.2019.1615215.

McCullagh, R 1989 'Excavations at Newton, Islay', Glasgow Archaeological Journal 15: 23-51.

McCullagh, R \& Tipping, R 1998 The Lairg Project 1988-1996: The Evolution of an Archaeological Landscape in Northern Scotland. Edinburgh: Scottish Trust for Archaeological Research.

Macphail, R I 1990 'The soils', in Saville, A (ed) Hazleton North, Gloucestershire, 1979-82: The Excavation of a Neolithic Long Cairn of the Cotswold-Severn Group, 223-6. London: HBMCE Archaeological Report 13.

Macphail, R I, Courty, M A \& Gebhardt, A 1990 'Soil micromorphological evidence of early agriculture in north-west Europe', World Archaeology 22(1): 53-69.

Mischka, D 2011 'The Neolithic burial sequence at Flintbek LA 3, north Germany, and its cart tracks: a precise chronology', Antiquity 85 : 742-58.

Morrison, A \& Pollard, T 1994 'Halmie (Latheron Parish), prehistoric cairn', Discovery and Excavation in Scotland 1994: 32-3.

Murray, H K \& Murray, J C 2013 'Midmill Industrial Estate, Kintore, Aberdeenshire: Archaeological Evaluations and Excavations carried out 2007-2012', unpublished report, Murray Archaeological Services Ltd, report no. MAS 2013-10.

Murray, H K, Murray, J C \& Fraser, S M 2009 A Tale of Unknown Unknowns: A Mesolithic Pit Alignment and a Neolithic Timber Hall at Warren Field, Crathes, Aberdeenshire. Oxford: Oxbow Books. 
Noble, G 2006 Neolithic Scotland: Timber, Stone, Earth and Fire. Edinburgh: Edinburgh University Press.

Noble, G \& Brophy, K 2011 'Ritual and remembrance at a prehistoric ceremonial complex in central Scotland: excavations at Forteviot, Perth and Kinross', Antiquity 85: 787-804.

Nobles, G R 2014 'Features', in Theunissen, E M, Brinkkemper, O, Lauwerier, R C G M, Smit, B I \& van der Jagt, I M M (eds) A Mosaic of Habitation at Zeewijk (the Netherlands): Late Neolithic Behavioural Variability in a Dynamic Landscape, pp. 39-54. Nederlandse Archeologische Rapporten 047. Cultural Heritage Agency of the Netherlands, Amersfoort.

O’Connell, M, Molloy, K \& Jennings, E 2020 'Long-term human impact and environmental change in mid-western Ireland, with particular reference to Céide Fields - an overview', Quaternary Science Journal 69: 1-32.

Parducci, L, Bennett, K D, Ficetola, G F, Greve Alsos, I, Suyama, Y, Wood, J R \& Pedersen, M K 2017 'Ancient plant DNA in lake sediments', New Phytologist 214: 924-42.

Pryor, F 2005 Flag Fen: Life and Death of a Prehistoric Landscape. Stroud: Tempus.

Reynolds, P 1981 'Deadstock and livestock', in Mercer, R (ed) Farming Practice in British Prehistory, 97-122. Edinburgh: Edinburgh University Press.

Rideout, J S 1996 'Carn Dubh, Moulin, Perthshire: survey and excavation of an archaeological landscape 1987-90', Proc Soc Antiq Scot 125: 139-95.

Ritchie, A 1983 'Excavation of a Neolithic farmstead at Knap of Howar, Papa Westray, Orkney', Proc Soc Antiq Scot 113: 40-121.

Romaniuk, A A, Panciroli, E, Buckley, M, Pal Chowdhury, M, Willars, C, Herman, J S et al 2020 'Combined visual and biochemical analyses confirm depositor and diet for Neolithic coprolites from Skara Brae', Archaeological and Anthropological Sciences 12(274) https://doi.org/10.1007/s12520-02001225-9.

Romans, J C C 1986 'Some notes on the soils at Scord of Brouster, Shetland', in Whittle, A M,
Keith-Lucas, A, Miles, B, Noddle, S, Rees, S \& Romans, J C C (eds) Scord of Brouster: An Early Agricultural Settlement on Shetland, Excavations 1977-1979, 125-31. Oxford: Oxford University Committee for Archaeology.

Romans, J C \& Robertson, L 1983 'The general effects of early agriculture on the soil profile', in Maxwell, G S (ed) The Impact of Aerial Reconnaissance on Archaeology, 136-41. London: Council for British Archaeology.

Rowley-Conwy, P, Gron, K J, Bishop, R R, Dunne, J, Evershed, R, Longford, C, Schulting, R $\&$ Treasure, E 2020 'The earliest farming in Britain: towards a new synthesis', in Gron, K J, Sørensen, L \& Rowley-Conwy, P (eds) Farmers at the Frontier: A Pan-European Perspective on Neolithisation, 401-24. Oxford: Oxbow Books.

ScARF 2012 Sheridan, A \& Brophy, K (eds) Neolithic Panel Report, Scottish Archaeological Research Framework: Society of Antiquaries of Scotland. http:// www.scottishheritagehub.com/content/scarfneolithic-panel-report. Accessed 27 March 2018.

Simpson, I A, Dockrill, S J, Bull, I D \& Evershed, R P 1998 'Early anthropogenic soil formation at Tofts Ness, Sanday, Orkney', Journal of Archaeological Science 25: 729-46.

Smith, I F \& Evans, J G 1968 'Excavation of two long barrows in north Wiltshire', Antiquity 42: 138-42.

Sørensen, L 2014 'From hunter to farmer in northern Europe: migration and adaptation during the Neolithic and Bronze Age', Acta Archaeologica 85(2): 1-305.

Stevens, C J \& Fuller, D Q 2012 'Did Neolithic farming fail? The case for a Bronze Age agricultural revolution in the British Isles', Antiquity 86: 707-22.

Suddaby, I 2015 'Aberdeen Western Peripheral Road', Discovery and Excavation in Scotland New Series 2015: 12-13.

Suddaby, I forthcoming 'Excavations at Vale of Leven Hospital, Alexandria, West Dunbartonshire', Scottish Archaeological Internet Reports.

Taylor, K \& Hunter, T 2000 'Excavation of subpeat agricultural features on Machrie Moor, 
Arran', Scottish Archaeological Journal 22(2): 179-86.

Telford, D 2019 'Transition Trauma: A Case-

Study of Coping with Becoming Neolithic', unpublished $\mathrm{PhD}$ thesis, University of Glasgow.

Thomas, J 1999 Understanding the Neolithic. London: Routledge.

Thomas, J 2013 The Birth of Neolithic Britain: An Interpretive Account. Oxford: Oxford University Press.

Treasure, E R, Grocke, D R, Caseldine, A E \& Church, M J 2020 'Neolithic farming and wild plant exploitation in western Britain: archaeobotanical and crop stable isotope evidence from Wales (c. 4000-2200 cal BC)', Proceedings of the Prehistoric Society 85 : 193-222.

Turner, V 1998 Ancient Shetland. Edinburgh: Batsford.

Turner, V 2013a 'Location, Form and Function in Shetland's Prehistoric Field Systems', unpublished $\mathrm{PhD}$ thesis, University of Stirling.

Turner, V 2013b 'Living off the land', in Mahler, D L (ed) The Border of Farming: Shetland and Scandinavia Neolithic and Bronze Age Farming, 24-34. Copenhagen: The National Museum of Denmark.

Wessex Archaeology 2008 Allasdale Dunes, Barra, Western Isles, Scotland: Archaeological Evaluation and Assessment of Results.
Salisbury: Wessex Archaeology Report 65305.01 .

Whitefield, A 2017 'Neolithic "Celtic" fields? A reinterpretation of the chronological evidence from Céide Fields in Northwestern Ireland', European Journal of Archaeology 20(2): 257-79.

Whitehouse, N J, Schultings, R, McClatchie, M, Barratt, P, McLaughlin, T R, Bogaard, A et al 2014 'Neolithic agriculture on the European western frontier: the boom and bust of early farming in Ireland', Journal of Archaeological Science 51: 181-205.

Whittle, A M, Keith-Lucas, A, Miles, B, Noddle, S, Rees, S \& Romans, J C C 1986 Scord of Brouster: An Early Agricultural Settlement on Shetland, Excavations 1977-1979. Oxford: Oxford University Committee for Archaeology. Whittle, A, Healy, F \& Bayliss, A 2011 Gathering Time: Dating the Early Neolithic Enclosures of Southern Britain and Ireland. Oxford: Oxbow Books.

Wright, D 2015 'Perth and Kinross, Wellhill: SERF, Test pitting, geophysics and excavation', Discovery and Excavation in Scotland New Series 15: 163-4.

Wright, D \& Brophy, K in prep Prehistoric Dunning: Excavations of a Prehistoric Farming and Settlement Landscape. York: Council for British Archaeology (SERF Project Monograph 3).

This paper is published with the aid of a grant from Historic Environment Scotland

The online version of this paper is available in open access under the terms of the Creative Com-mons Attribution-NonCommercial 4.0 International licence (CC BY-NC 4.0) https://creativecom-mons.org/ licenses/by-nc/4.0 